HELLE MERETE NORDENTOFT

KRISTINA MARIAGER-ANDERSON

ANNE SMEDEGAARD

\title{
KOLLEKTIV AKADEMISK \\ VEJLEDNING \\ EN INTRODUKTION
}

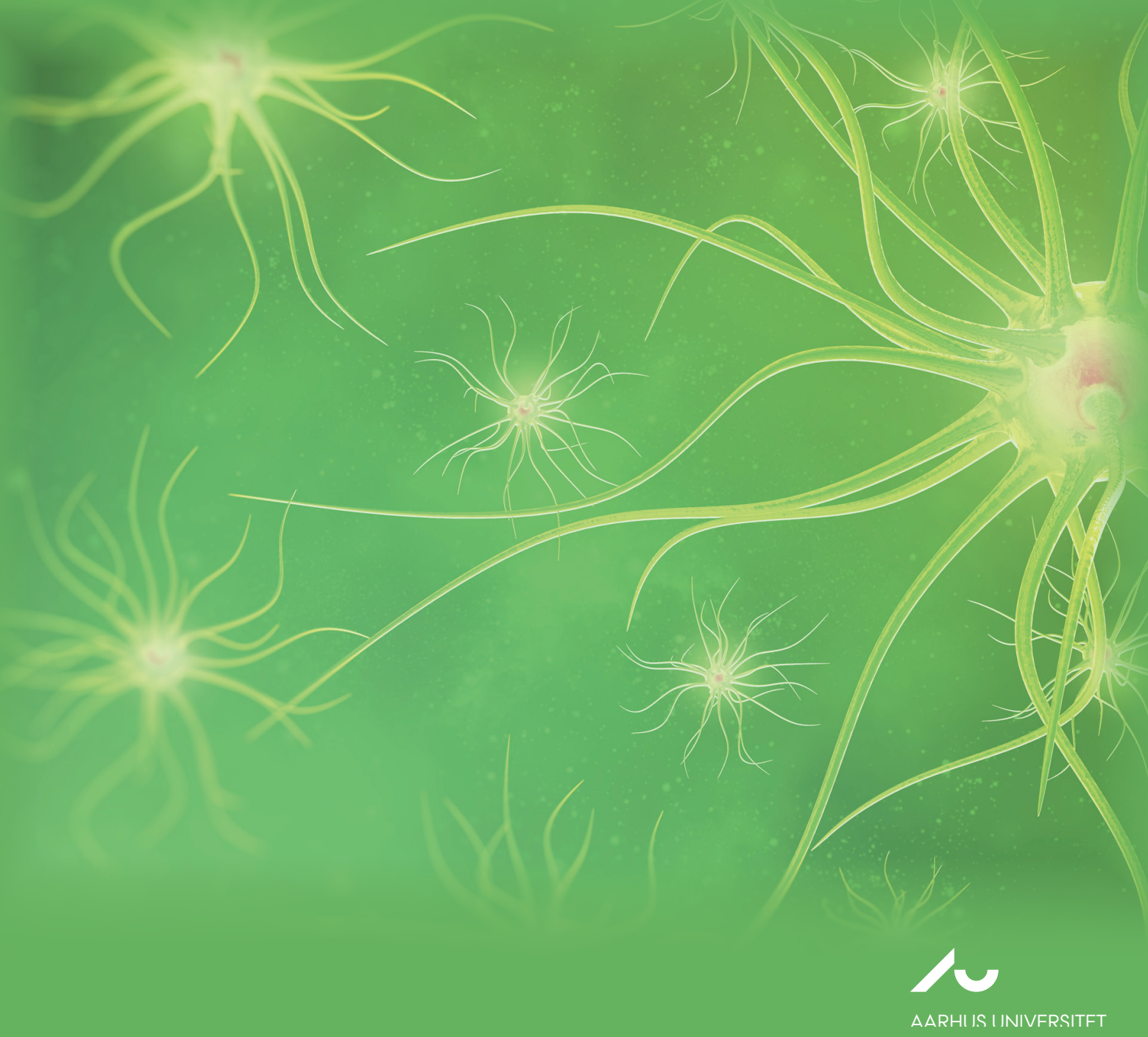



Helle Merete Nordentoft, Kristina Mariager-Anderson og Anne Smedegaard

\section{KOLLEKTIV AKADEMISK VEJLEDNING \\ En introduktion}

DPU, Aarhus Universitet, 2016 
Titel:

Kollektiv Akademisk Vejledning - en introduktion

Forfattere:

Helle Merete Nordentoft, Kristina Mariager-Anderson og Anne Smedegaard

Udgivet af:

DPU, Aarhus Universitet, 2016

(C) 2016, forfatterne

1. udgave

Kopiering tilladt med tydelig kildeangivelse

Omslag og grafisk tilretteløeggelse:

Knud Holt Nielsen

Forsidefoto:

Colourbox

ISBN:

978-87-7684-706-7 (elektronisk)

978-87-7684-707-4

DOI:

10.7146/aul. 144.123 


\section{Indhold}

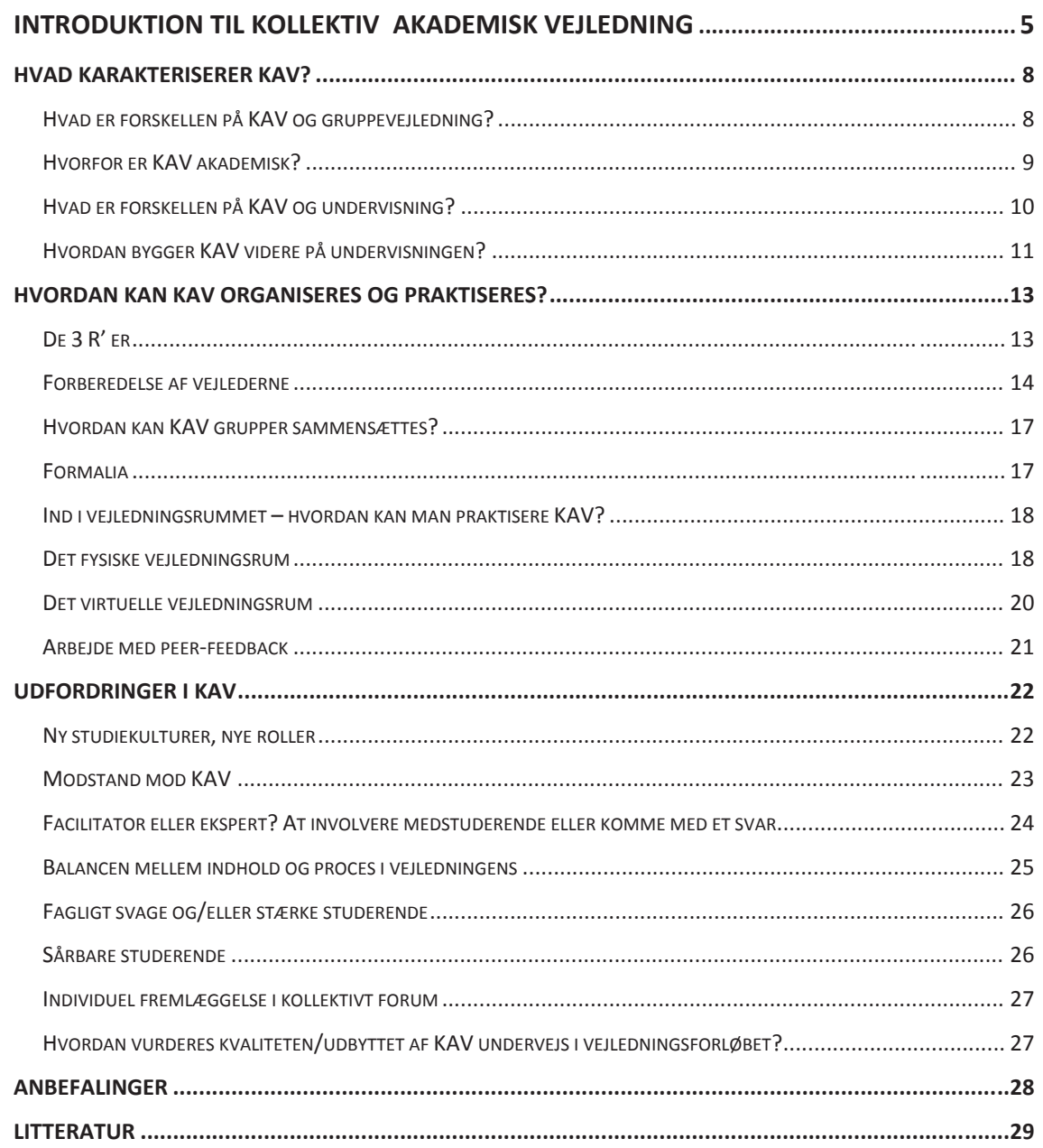




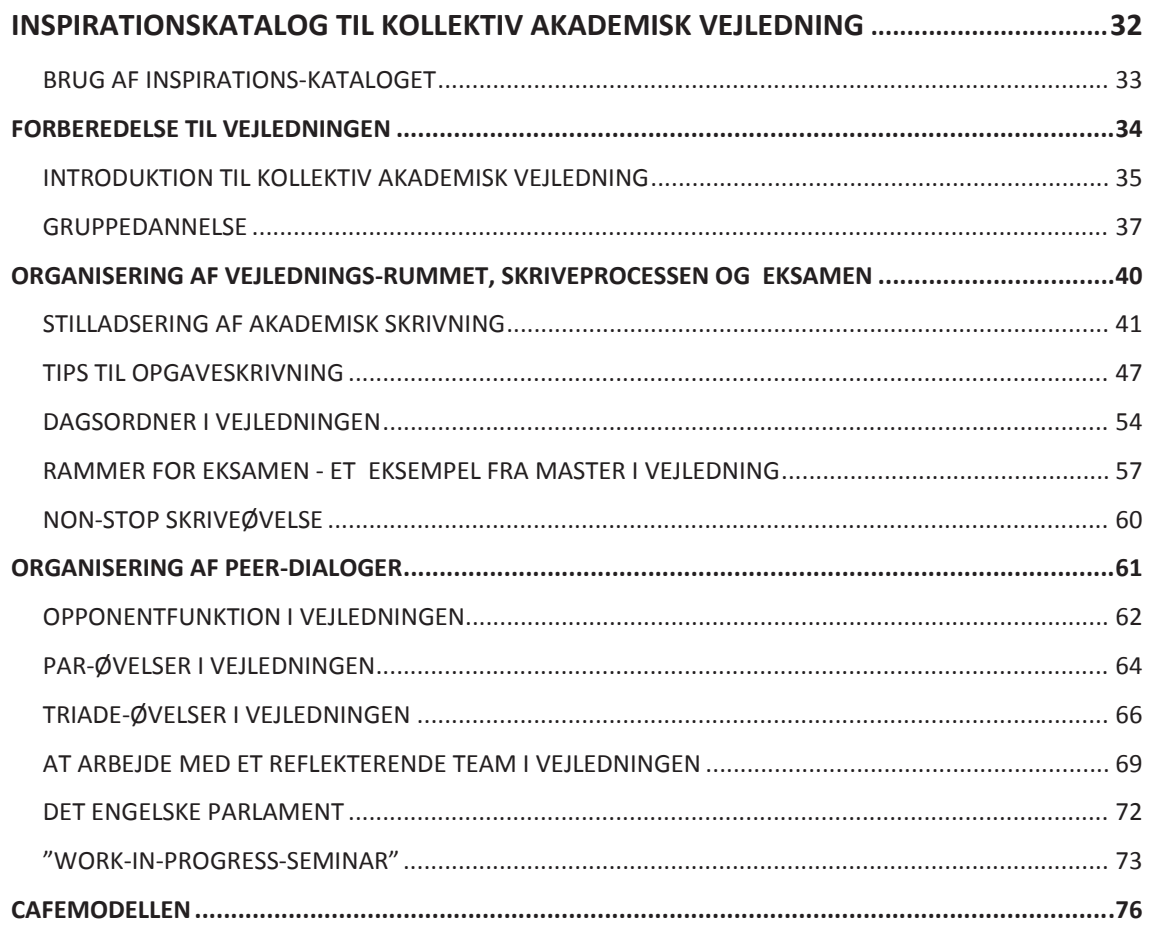




\section{Introduktion til Kollektiv Akademisk Vejledning}

"It is the tension between diverging voices that creates the potential for new under-standings." (Dysthe, Samara \& Westrheim, 2006, s. 314)

Formålet med Kollektiv Akademisk Vejledning (KAV) er at introducere en kollektiv akademisk arbejdsform via vejledning, "hvor de studerende fär erfaringer med at præsentere og diskutere faglige spørgsmål" i et kollektivt forum (Thomsen \& Nordentoft, 2012, s. 107). Siden 2009 har vi arbejdet med KAV på Master i Vejledning og det er vores erfaring at $\mathrm{KAV}$

- Hjælper de studerende til at komme tidligere i gang med og få afgrænset deres opgave.

- Giver de studerende faglige input til deres skrivning gennem sparring ikke kun fra vejlederen men også fra medstuderende

- Er med til at udvikle og øge de studerendes studiemotivation og skrivelyst

- Faciliterer skarpere problemformuleringer

- Giver bedre eksaminer

- Skaber mere og bedre samvær mellem de studerende

- Bidrager til kollegial sparring og kompetenceudvikling og et bedre arbejdsmiljø!

Når ovenstående er sagt - er det ikke uden udfordringer at praktisere Kollektiv Akademisk Vejledning (KAV). Vores erfaring og videnskabelige arbejde giver et klart fingerpeg om, at kollektive vejledningsformer betyder et kulturskifte for både vejledere og studerende, som er vant til individuel vejledning. For vejleder betyder det for det første et øget fokus på og forberedelse ift., hvordan vejledningsrummet kan organiseres - og ikke 'kun' den indholdsmæssige del af vejledningen. For det andet må vejlederen før, under og efter vejledningen formidle ikke kun, hvordan vejledningen er organiseret - men også hvorfor ift. de mål, som står beskrevet i studieordningen for at komme evt. indvendinger fra de studerende i forkøbet. For de studerende kan det opleves som udfordrende at blive vejledt i en kollektiv sammenhæng med et mindre fokus på de individuelle projekter. Hvis ikke der skabes en tydelig ramme omkring vejledningen, kan det gøre de studerende usikre, så de bliver i tvivl om, hvad der forven- 
tes af dem - og om det udbytte de tilbydes i vejledningen, matcher lige præcis deres behov $^{1}$. Derfor er det helt centralt, at vejlederen har tænkt vejledningens formål igennem og kommunikerer disse både på skrift og mundtligt før, under og efter vejledningen. Sidst men ikke mindst siger vi til de studerende, at de kan betragte vejledningsrummet som et laboratorium ift. at lære nogle af de ikke kun indholdsmæssige, men også strukturelle akademiske kompetencer, som de forventes at få med sig fra deres master eller kandidat studie. Denne læring sker gennem den måde, som KAV rummet er organiseret på, hvor peer dialoger er et centralt omdrejningspunkt. I vejledningsrummet lærer de studerende, hvordan de kan modtage og give feedback i en akademisk kontekst, samt hvordan frugtbare dialoger i grupper eller større fora kan faciliteres.

Et centralt formål med KAV er desuden at styrke de studerendes robusthed i forhold til at arbejde målrettet med deres skriftlige opgaver i eksamensperioden. Håbet er, at det kollektive arbejde i grupperne bidrager til, at de studerende arbejder mere sammen i deres skriveproces, så de får øje på, at de ikke er alene om problemer, de oplever, og at de ser, at de er både almindelige og overkommelige. Disse erkendelser kan betyde, at flere studerende aflægger eksamen fremfor at melde fra. KAV kan dermed ses som ét bud på, hvordan de nuværende studiemæssige strukturer kan udvikles i takt med en kvalificering af studiekulturen, så der skabes øget fremdrift.

I denne introduktion uddyber vi det teoretiske og metodiske afsæt med det formål at etablere, udvikle og kvalificere KAV som vejledningspraksis på DPU - herunder de udfordringer, som vejlederen kan støde på i vejledningen. Introduktionen er $\underline{\text { kkke en }}$ bageopskrift på, hvordan en KAV kan implementeres, da dette kræver en indsigt i de lokale strukturelle og personalemæssige forhold på den enkelte uddannelse. Måske praktiserer I allerede kollektivt inspirerede vejledningsformer på din uddannelse? Hvis I gør det og har fundet en form, som giver mening for både vejledere og de studerende, så er det vigtigt at bygge videre på den. Vi håber, at I kan bruge denne introduktion som et input til at understøtte og kvalificere en kollektiv vejledningspraksis på din/jeres uddannelse. Vi vil opfordre til, at alle vejledere, som deltager i projektet, til at dele deres nye erkendelser undervejs i en mappe, som vi får lavet til projektet på black board (BB). Det kan være i form at nye måder at organisere det kollektive vejledningsrum på, nye øvelser og nye måder at undersøge de studerendes udbytte af vejledningen undervejs.

${ }^{1}$ I den sidste del af introduktionen uddyber vi de udfordringer, der kan være ved at vejlede kollektivt. 
I første del af introduktionen uddyber vi de pædagogiske rationaler bag KAV. Dernæst udfolder vi, hvordan vi siden 2009 har arbejdet med at udmønte disse principper på Master i Vejledning. Sidst i introduktionen har vi samlet øvelser og forslag til, hvordan KAV konkret kan praktiseres i et inspirationskatalog. KAV er desuden beskrevet i tre artikler (Nordentoft, Thomsen, \& Wichmann-Hansen, 2013; Thomsen \& Nordentoft, 2012; Wichmann-Hansen, Thomsen, \& Nordentoft, 2015) , som i kronologisk rækkefølge uddyber følgende tematikker:

- Thomsen \& Nordentoft (2012) beskriver rationalet for at udvikle KAV, og hvordan det kan gøres i et organisatorisk perspektiv.

- Nordentoft, Thomsen \& Wichmann-Hansen (2013) uddyber det samme på engelsk og inddrager desuden interview med studerende med det formål at beskrive, hvordan de oplever KAV.

- Wichmann-Hansen, Thomsen og Nordentoft (2015) går tættere på vejledernes oplevelse af de udfordringer, der kan være ved KAV. 


\section{Hvad karakteriserer KAV?}

I vores beskrivelse af KAV tager vi afsæt i tre centrale spørgsmål, som vi ofte bliver stillet, når vi fortæller om KAV.

\section{Hvad er forskellen på KAV og gruppevejledning?}

I KAV vejledes flere studerende, som skriver på forskellige opgaver/projekter, sammen. KAV er således ikke det samme som gruppevejledning. Rationalet i KAV er netop at integrere og skabe en dynamik mellem forskellige perspektiver indenfor et fagområde, dvs. forskelle mellem individuelle opgaver/projekter og/eller gruppeopgaver og dermed skabe fælles læring i vejledningsgruppen (Igland \& Dysthe, 2003; Nordentoft et al., 2013; Thomsen \& Nordentoft, 2012). Disse forskelle bruges som en drivkraft i vejledningen i forhold til at blive klogere på, hvad de konkret handler om, og hvordan de kan begribes i forhold til den kontekst, som de er opstået i. Hvilke implikationer har forskellige teoretiske perspektiver fx i forhold til metodevalg? Ikke mindst styrker processen med at forstå disse forskelle og deres betydning en afklaring af, hvad det er, som særligt karakteriserer den studerendes eget projekt. I udviklingen af KAV har vi arbejdet med mindre vejledningsgrupper på 4-6 studerende, men ovenstående tankegang kan også praktiseres i større grupper. Kunsten for vejlederen er at balancere mellem at sætte en klar og målorienteret ramme for vejledningen og at give tid og plads til de studerendes spørgsmål og input i/til vejledningen

Læringsteoretisk bygger KAV således på et sociokulturelt grundlag, som er nært knyttet til Lave \& Wenger, Bakhtin og Dysthe (Bakhtin, 1981; Dysthe, 2003; Igland \& Dysthe, 2003; Lave \& Wenger, 1991). Her er forståelsen og udbyttet af læring og vidensproduktion kontekstuelt og relationelt funderet og forankret i de lærendes dialoger og deltagelse. En normativ traditionel forståelse af dialog lægger vægt på et møde mellem to ligeværdige mennesker, hvor målet er at skabe en fælles forståelse. Den russiske litteraturteoretiker Bakhtin, tilbyder en lidt anden forståelse, hvor der lægges der vægt på, at dialogen giver plads til at udtrykke modsatrettede holdninger. I hans optik repræsenterer dialogen et møde mellem forskellige stemmer, som er et udtryk for forskellige ideer, standpunkter og meningsuniverser. Desuden veksler dialogen mellem to samtidige og modsatrettede bevægelser: Centripetale bevægelser, som kan være udsagn, der samler forskellige synspunkter i en dialog og skaber konsensus, og centri- 
fugale bevægelser som spreder og bidrager til at skabe uenighed og dissensus i dialogen (Dalgaard, Johannsen, Kristiansen, \& Bloch-Poulsen, 2014).

Som vejleder er det øvelsen at give plads til begge bevægelser i en dialogisk proces og formå at bringe den til en afslutning, hvor forskellighederne ikke forvirrer de studerende, men at de kan være afklarende ift. at belyse den kompleksitet, der ofte er til stede indenfor et givent tema. Hvordan det kan gøres, skriver vi mere om i den del af introduktionen, hvor vi uddyber, hvordan principperne i KAV konkret kan udmøntes.

\section{Hvorfor er KAV akademisk?}

KAV står som nævnt for Kollektiv Akademisk Vejledning. Med akademisk ønsker vi for det første at understrege betydningen af, at vejledningen foregår i en akademisk kontekst, hvor der stilles bestemte krav til de studerende. For det andet er vejledning en central læringsaktivitet i udviklingen af akademiske kompetencer.

I KAV får de studerende anledning til at øve sig på centrale akademisk dyder, nemlig at give og modtage kritik af egne/andres projekter i vejledningen både skriftligt og mundtligt (Lillejord \& Dysthe, 2008). KAV praktiseres derfor bedst i mindre grupper, hvor den enkelte studerende har mere taletid, og hvor han/hun på baggrund af et skriftligt udgangspunkt mundtligt har mulighed for at øve sig i færdigheder, som knytter sig til videnskabelige kompetencer beskrevet i studieordningen. I vejledningen er det således en ambition at arbejde systematisk på at facilitere en konstruktiv synergi mellem skriftlighed og mundtlighed. En grundlæggende tese i KAV er, at gode dialogiske processer skaber mere afklarede og tilfredse studerende og dermed også bedre opgaver og eksaminer. I arbejdet hen imod at styrke de studerendes argumentation i de akademiske funderede dialoger fungerer gruppens forskellighed som en drivkraft, der kan fremme de studerendes analytiske og kritiske blik ift. at få øje på de muligheder og begrænsninger et givent teoretisk og analytisk perspektiv rummer. Et centralt fokus er arbejdet med at kvalificere akademisk funderede spørgsmål såvel i problemformuleringen som i dialogerne. Konkret betyder det, at vejlederen må afveje, om de spørgsmål, som de studerende stiller bedst besvares af vejlederen, eller med fordel kan adresseres, kvalificeres og måske besvares i plenum. Den fælles dialog giver mulighed for, at de studerende formulerer og reflekterer over deres egne fag- og forforståelser, bekymringer og problemer samt lytter på og er med til at udvikle hinandens forståelser af det faglige stof. I hele denne refleksionsproces er det vejlederens rolle at strukturere dialogerne og vurdere, hvornår der er behov for at tydeliggøre mulige konklusioner så 
de studerende ikke forvirres over den mulige kompleksitet, som udfoldes i vejledningsrummet.

Arbejdet med spørgsmål og svarmuligheder giver mulighed for, at vejlederen stilladserer de studerendes tilegnelse af akademiske argumentationsformer (Perregaard, 2002; Vygotsky, 1978). Kvalificering af spørgsmål styrker de akademiske dialoger og sætter samtidig de studerende på sporet af, hvordan man ræsonnerer på akademiske måder i både mundtlige og skriftlige akademiske genrer. I vejledningen kan de fx udvikle deres forståelse af sammenhængen mellem spørgsmål, hypoteser, undersøgelsesmetoder, empiri og teori. I KAV er introduktionen af akademisk diskurs dobbelt: Akademisk diskurs anvendes og tematiseres og ekspliciteres. Netop denne dobbelthed er spændende didaktisk, fordi den giver vejlederen mulighed for at udnytte de læringsperspektiver, der knytter sig til metarefleksion. Det er f.eks. vigtigt, at centrale akademiske begreber (diskurs, magt etc.) og sproghandlinger (beskrivelse, redegørelse etc.) som både anvendes i vejledningen og i de studerendes tekster defineres og eksemplificeres som en del af vejledningen. Hvordan det kan foregå kommer vi med konkrete bud på i inspirationskataloget.

Sammenfattende giver det kollektive forum plads til flere måder at deltage på - og skaber dermed mulighed for læring på flere niveauer (Thomsen, Boelskifte Skovhus, \& Buhl, 2013). KAV giver de studerende mulighed for at:

- veksle mellem at lytte, skrive og tale

- høre og se, hvad andre spørger om og får svar på

- få ideer til spørgsmål, man selv kunne stille

- fremlægge og argumentere for en teoretisk/metodisk position

- få indblik i andres arbejdsprocesser og måder at gribe opgaveskrivning an på

- drøfte tidligere spørgsmål og samtaler med andre, som også har hørt, hvad der er blevet sagt (i/udenfor vejledningsrummet)

\section{Hvad er forskellen på KAV og undervisning?}

Når flere studerende skal vejledes i det samme rum, falder både de studerende og vejlederne let tilbage i en mere monologisk undervisningsform, hvor de studerende stiller spørgsmål, som vejlederen svarer på. Forskellen på undervisning og vejledning er netop, at vejlederen tager afsæt i den studerendes aktuelle behov fremfor at forelæse over de problematikker, som vejlederen finder centrale. Udfordringen er, hvordan vejlederen tidsmæssigt og indholdsmæssigt kan nå at skabe kvalitet i vejledningen i forhold 
til de mål, der er beskrevet i studieordningen, når studerende med forskellige behov skal vejledes samtidigt.

I udviklingen af KAV har vi arbejdet med at skabe en synergi mellem at vejlede på henholdsvis et eksemplarisk og et individuelt niveau og yderligere at være meget tydelige i forhold til, hvornår det ene eller andet niveau er i spil vejledningen (Lauvås \& Handal, 2006). Fx oplever vejledere ofte, at de studerende spørger om det samme, og/eller at det er de samme udfordringer, som de studerende slås med i deres proces. I vejledningen er det derfor oplagt og tidsbesparende at fremhæve et eksemplarisk niveau i vejledningen i den indledende del. Vejlederen kan fx samle og kommentere ligheder i de skriftlige oplæg, som er fremsendt inden vejledningen, i en PowerPointpræsentation eller et handout, som gennemgås i starten af vejledningen.

Det er væsentligt, at vejlederen formidler formålet for denne struktur til de studerende, da den fordrer, at de studerende kan foretage et skifte fra at være i en undervisningslignende situation og dermed være i en overvejende passiv og lyttende position, når vejlederen kommenterer på de generelle problematikker i deres skriftlige oplæg til vejledningen, til at være aktivt deltagende i dialogen bagefter. Det er dog ikke sikkert, at de studerende formår at forbinde de generelle perspektiver, som vejlederen introducerer, med deres egne problematikker. Her kan en deltagerorienteret dialog bagefter fx parvise dialoger med en opsamling i plenum - evt. give et tydeligt fingerpeg, ift. om, de studerende har kunnet integrere vejlederens kommentarer med deres eget materiale. Vejlederens viden om akademiske genrer og diskurser må derfor sættes i spil før og efter deltagerorienterede dialoger, således at disse ikke åbner for usikkerheder hos den enkelte studerende, men i stedet fører frem til større afklarethed om bedømmelseskriterier for eksamensopgaverne samt om skriveprocessens faser

\section{Hvordan bygger KAV videre på undervisningen?}

Den undervisning, der går forud for KAV, har givet de studerende faglig viden samt en bunke akademisk litteratur, som de skal skrive om - og ud fra - i deres eksamensopgaver. Den har desuden også givet dem en indføring i akademiske genrer, sproghandlinger og diskurser - både mundtlige og skriftlige. I undervisningen og pensumlistens litteratur bruges der faglige begreber, og der ræsonneres på akademisk forsvarlige måder. At skrive en god opgave kræver, at man kan tilegne sig disse særlige, faglige tænkemåder (Hyland, 2003, 2009). Nogle studerende aflurer nemt de implicitte kvalitetskriterier, som knytter sig til forskningen i et bestemt felt og lægger mærke til, hvordan et godt akademisk spørgsmål ser ud, og hvilke typer af handlinger det kræver at 
give et godt svar. Handlinger refererer her både til opgavestrukturerende handlinger (f.eks. indledning/problemformulering, teori, metode, analyse, konklusion/perspektivering/diskussion) og de førnævnte akademiske sproghandlinger (f.eks. argumentation, beskrivelse og definition). For andre studerende er denne proces sværere. I inspirationskataloget kommer vi med bud på, hvordan vejlederen kan arbejde med at eksplicitere de særlige sproglige, diskursive og genremæssige træk ved akademisk argumentation og hjælpe de studerende med at videreudvikle den måde, de selv griber faglige problematikker an på, så de bliver mere akademiske.

Der er fx visse ligheder mellem de krav, der stilles til universitetsopgaver, og de krav, der stilles til akademiske artikler. Dette kan udnyttes didaktisk. En mulighed er at finde eksempler på f.eks. indledninger, problemformuleringer, metodeafsnit, teoriafsnit, analyseafsnit, konklusioner, perspektiveringer og diskussioner i den litteratur, der er læst og gennemgået i undervisningen, og som de studerende derfor kender. I KAV kan de studerende sammen med vejlederen undersøge, hvordan skribenterne her gør akademiske handlinger og få øje på, hvordan en god akademisk tekst kan struktureres. Denne øvelse giver ligeledes indsigt i de krav, der stilles til en akademisk tekst. I arbejdet med at afkode de akademisk krav til skriftlige produktioner kan vejlederen desuden inddrage forskellige eksempler fra tidligere studerendes opgaver for at illustrere spillerummet i akademisk skrivning (Swales, 2004, 2008). Desuden kan undersøgelsesprocessen med fordel inddrage et kritisk perspektiv (Devitt, 1997, 2004) hvor de studerende reflekterer over spørgsmål så som: Hvordan kunne eksempelteksterne formuleres skarpere? Eller måske mere læsevenligt? Hvilke perspektiver udelades i eksempelteksterne? Hvilke forforståelser forudsætter de? En sådan form for stilladsering kan synes som en tidskrævende proces. Men forskningen og vores erfaring viser, at tiden er givet godt ud, da de studerende får tydelige forbilleder at søge inspiration hos, mens de skriver. Sidst men ikke mindst er det en stor fordel for læringsudbyttet, hvis der er et tæt samarbejde mellem undervisere og vejledere i skriveprocessen, så der opstår en sammenhæng mellem undervisning, vejledning og opgaveskrivning. 


\section{Hvordan kan KAV organiseres og praktiseres?}

I dette afsnit beskriver vi, hvordan KAV kan organiseres og praktiseres. Vi introducerer til de grundlæggende principper i en KAV-proces, herunder:

- hvordan vejledningsgrupperne kan dannes

- hvordan deltagerne kan forberedes og mødes, inden vejledningen starter

- hvordan et vejledningsforløb med KAV kan udfoldes, herunder hvilke tematikker som tages op samt hvornår

- hvordan KAV kan praktiseres i vejledningsrummet

- hvilke udfordringer, som kan opstå undervejs

I inspirationskataloget kan læseren finde konkrete eksempler på, hvordan disse principper kan praktiseres.

\section{De 3 R' er}

KAV hviler på principper, som kan sammenfattes i de 3 R'er: Rammer, Ritualer og Reformuleringer (Nordentoft, 2011) 


\section{$\begin{array}{ll}14 & \text { KOLLEKTIV AKADEMISK VEJLEDNING } \\ \text { - EN INTRODUKTION }\end{array}$}

\begin{tabular}{|l|l|}
\hline Rammer & $\begin{array}{l}\text { De strukturelle rammer for vejledningen handler om forhandling } \\
\text { og beslutning om: } \\
\text { hvem der skal vejlede, } \\
-\quad \text { hvem der skal deltage i vejledningen, } \\
-\quad \text { hvor og hvornår, den skal foregå (samlet tidsforbrug) }\end{array}$ \\
\hline Ritualer & $\begin{array}{l}\text { Strukturelle gentagelser i vejledningsrummet. Det skaber tryghed } \\
\text { og et godt afsæt for vejledningen, når vejlederen bygger vejlednin- } \\
\text { gen op på den samme måde hver gang. Hun kan evt. sammen med } \\
\text { de studerende ændre denne opbygning undervejs. I inspirationska- } \\
\text { taloget bagerst i denne introduktion giver vi eksempler på, hvor- } \\
\text { dan dette kan gøres. }\end{array}$ \\
\hline Reformuleringer & $\begin{array}{l}\text { Reformuleringer er et grundlæggende element i enhver dialog med } \\
\text { henblik på at opnå en fælles forståelse af, hvad det er for en pro- } \\
\text { blematik, der er i spil. Da vejledningens afsæt er de studerendes } \\
\text { behov, arbejder vejleder med at konkretisere, hvad disse behov er, } \\
\text { ved selv at reformulere de studerendes udsagn mundtligt og skrift- } \\
\text { ligt. Her kan en whiteboard eller flipover tages i brug. Vejlednings- } \\
\text { processen understøttes desuden af en række par-, triade- og grup- } \\
\text { peøvelser i vejledningsrummet. Se eksempler på disse øvelser i } \\
\text { inspirationskataloget. }\end{array}$ \\
\hline
\end{tabular}

\section{Forberedelse af vejlederne}

Som forberedelse til KAV har vi erfaret, at det er meget konstruktivt at holde 2-3 møder i vejledningsforløbet, hvor alle vejledere på et modul er til stede. Dvs. et fælles møde inden modulet starter, eventuelt et midt i forløbet og et efter, de studerende har afleveret deres opgave. Formålet med disse møder er at udveksle erfaringer og tanker ift. at vejlede kollektivt. Disse samtaler med ligestillede kan bidrage til at styrke den enkelte vejleders praksis. Vores forskning viser desuden, at de studerende er meget opmærksomme på, hvis der er forskel på, hvor meget den enkelte vejleder fx tilbyder individuel vejledning. Derfor kan det være en god idé at skabe fælles rammer for, hvordan man som vejleder vil organisere vejledningen tidsmæssigt, så de studerende oplever at få den samme tid. På mødet efter de studerende har afleveret deres opgaver, kan vejlederne $\mathrm{fx}$ vende forholdet mellem, hvordan vejledningen er gået og kvaliteten 
af eksamensopgaverne. Undervejs i vejledningsforløbet kan det også være en god idé at praktisere kollegial vejledning/sparring eller supervision (Andersen \& Bager, 2011; Nordentoft, 2012; Nordentoft \& Wistoft, 2012). I dette forum kan vejlederne overvære hinandens vejledning og formulere, diskutere og får kollegial feedback på de udfordringer, som de arbejder med at håndtere i vejledningen.

\section{Forberedelse af de studerende}

\section{Vejlederbrev - en introduktion til KAV}

Alle studerende får et vejlederbrev, som er en skriftlig introduktion til, hvad KAV er, og hvordan denne vejledningsform praktiseres (se inspirationskataloget). Den skriftlige introduktion gør klart, hvad der i forløbet forventes af dem, herunder særligt at de skal være indstillet på at bidrage aktivt til dialogerne i vejledningen, læse medstuderendes tekster og give peerfeedback. Disse er grundlæggende præmisser for det dialogiske rum i KAV, som de studerende skal kende til.

\section{Tidligere studerende}

Information om KAV kan derudover gives til de nye studerende af tidligere studerende, som inviteres en af de første undervisningsgange til at fortælle om, hvordan de har oplevet vejledning i en KAV-gruppe, og hvordan de har arbejdet med deres opgave i processen. Dette giver en god mulighed for en videre forventningsafstemning mellem vejlederen og de nye studerende. Samtidig giver samarbejdet med de tidligere studerende anledning til at bede dem om tilladelse til at lægge deres opgaver på intranettet, så de nye studerende kan få en klar idé om, hvad slutmålet for vejledningen er. Ved at henvise til de opgaver, som ligger på intranettet, kan vejlederen besvare mange formelle spørgsmål. Grundig information om, hvad der formelt og indholdsmæssigt forventes af de studerende, sparer kostbar tid i vejledningen. Opgaverne kan samtidig inddrages i undervisningen, hvor de kan give klargøende eksempler på, hvordan fagets emner kan behandles i selvstændige opgaver.

\section{Eksempel på prototypisk vejledningsforløb}

I den skematiske oversigt nedenfor kan læseren se en prototype på en tids- og tematisk struktur i et vejledningsforløb, herunder hvordan de studerende forventes at forberede sig til vejledningen. I "Opgave og skrivevejledning i klynger" kan læseren få yderligere inspiration til, hvordan et vejledningsforløb kan struktureres (Jensen, 2015). 


\section{KOLLEKTIV AKADEMISK VEJLEDNING \\ - EN INTRODUKTION}

\section{Tidspunkt Tema i vejledningen Forberedelse}

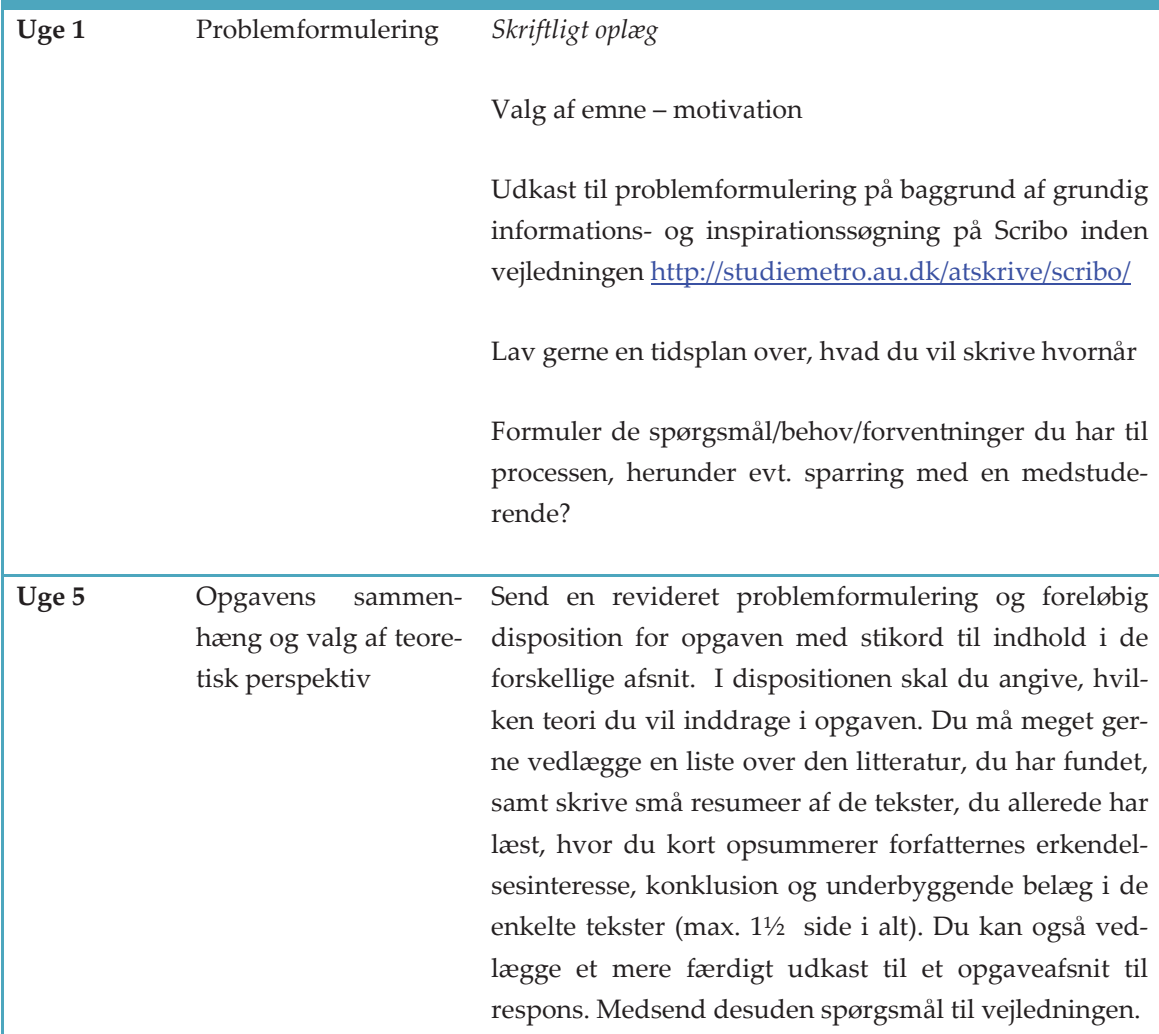

Uge 10 Analyse og diskussion Til denne vejledning skal du helst sende et eks. på din analyse. Der skal som minimum sendes a) problemformulering, b) uddybning af hvordan denne skal undersøges, c) forslag til en kommenteret indholdsfortegnelse, hvor der står, hvad de forskellige afsnit skal indeholde og d) en litteraturliste. Medsend desuden spørgsmål til vejledningen.

Uge 12-14 Skriftlig respons pr. Send et udkast til en indledning, et analyseafsnit og en mail på analyse og disposition for opgavens diskussionen.

diskussion - maks. 10

sider. 


\section{Hvordan kan KAV grupper sammensœttes?}

En KAV-gruppe består ideelt set af 4-6 individuelle projekter, men der KAV kan også praktiseres $i$ et større forum. Fx kan en vejledningsgruppe bestå af flere gruppeprojekter (fx 4-6), som repræsenteret i den kollektive vejledningsgruppe og dermed også 4-6 forskellige tematikker og evt. teoretiske/metodiske perspektiver. En KAV-gruppe kan sammensættes på mange forskellige måder, da den forskellighed, som er drivkraften i $\mathrm{KAV}$, kan manifestere sig på flere måder. Der kan være en gruppe, som arbejder med det samme tema, som behandles på forskellige måder. Forskelle i, hvordan temaet undersøges, bliver så et centralt omdrejningspunkt i vejledningen. Vejlederen kan fx spørge "Der er forskel på den måde, som John og Pia vil undersøge deres problemstilling. Hvilken betydning kan denne forskel fä for den viden de kan producere - med andre ord, hvad de hver især kan sige noget om?" Det samlende punkt kan også være, at gruppen arbejder med den samme metode, men indenfor forskellige felter. Endeligt kan det være, at en gruppe sammensættes med afsæt i en studiegruppe, hvor de studerende kender hinanden i forvejen.

På uddannelsens første modul sammensættes grupperne typisk tilfældigt, da de studerende ikke kender hinanden eller ved, hvad de vil skrive om. Med andre ord er den forskellighed, som viser sig på det første modul tilfældig, men den italesættes stadigt og udnyttes af vejlederen som en drivkraft i vejledningen. På de næste moduler kan de studerende ønske, hvilken gruppe de gerne vil være i. Mens grupperne på det første modul etableres inden semesterstart (så snart de studerendes navne er kendt), etableres grupperne på de følgende moduler i løbet af den første uge, når vi har fået de studerende ønsker. I inspirationskataloget er der et forslag til, hvordan man kan tilrettelægge en gruppedannelsesproces i et større forum.

Når grupperne er dannede, lægger vejlederne en oversigt over grupperne, de tematikker, som de arbejder med og deres vejledere på intranettet. Denne oversigt giver mulighed for, at grupperne kan kommunikere indbyrdes med hinanden. Desuden er der også oprettet en mappe til de enkelte grupper, så de kan kommunikere med hinanden der. Hvis de studerende vil skifte gruppe, siger vi til de studerende, at de selv må arrangere det og give besked til de to vejledere (den tidligere og den nye vejleder) og modulkoordinatoren, så hun kan ændre gruppen på BB.

\section{Formalia}

Oplysning om formalia ift. opgaveskrivningen - herunder eksamen, kan tage meget kostbar tid i en vejledning. Derfor har vi udarbejdet tips, som kan tilpasses lige præcis 
den modulopgave, som de studerende skal arbejde med. Desuden har vi lavet et handout, som retter sig mod eksamen ift. de forskellige moduler (se inspirationskataloget ift. tips til modulopgaver og eksamen). Endeligt lægger vi efter tilladelse fra de studerende en række tidligere opgaver på nettet, så de studerende kan se forskellige eksempler på, hvordan opgaven kan skrives. Så når de studerende spørger til formalia, henviser vi til disse elementer. Akademisk skrivecenter har også opgavebank, som de studerende kan benytte sig af.

\section{Ind i vejledningsrummet - hvordan kan man praktisere KAV?}

Vejledningen praktiseres i to forskellige rum, som ideelt set supplerer hinanden:

- Det fysiske vejledningsrum

- Det virtuelle vejledningsrum - på BB og pr. mail.

\section{Det fysiske vejledningsrum}

I skemaet nedenfor har vi beskrevet, hvordan et møde i en KAV-gruppe kan forløbe og dermed, hvordan man som vejleder kan skabe nogle gode ritualer i sit kollektive vejledningsrum. Der er tre forskellige bud på, hvordan de tre hoved- eller tidsfaser i et KAV-forløb kan udfyldes. Disse kan evt. også kombineres. 


\begin{tabular}{|c|c|c|c|}
\hline & Version 1 & Version 2 & Version 3 \\
\hline $\begin{array}{l}\text { Vejledningen } \\
1-1 \frac{1}{2} \text { time }\end{array}$ & $\begin{array}{l}\text { Parvis arbejde } i \\
\text { gruppen - fx i for- } \\
\text { hold til problem- } \\
\text { formulering } \\
\text { To forskellige må- } \\
\text { der/trin: } \\
\text { 1. Interview-øvelse } \\
\text { 2. Arbejde med en } \\
\text { andens problem- } \\
\text { formulering (begge } \\
\text { øvelser: Se inspira- } \\
\text { tionskataloget) }\end{array}$ & $\begin{array}{l}\text { Triader } \\
\text { To studerende inter- } \\
\text { viewer hinanden, } \\
\text { mens den } 3 \text {. lytter i } \\
\text { forhold til bestemte } \\
\text { kriterier, som på } \\
\text { forhånden er define- } \\
\text { ret. Det kan fx være i } \\
\text { forhold til pentago- } \\
\text { nen (Se inspirations- } \\
\text { kataloget) }\end{array}$ & $\begin{array}{l}\text { Reflekterende team } \\
\text { Vejlederen laver et interview med } \\
\text { en/to studerende i forhold til det, } \\
\text { den studerende har brug for respons } \\
\text { på, mens resten af gruppen lytter. } \\
\text { Vejlederen skriver de spørgsmål, } \\
\text { som den studerende har, på white } \\
\text { board og reflekterer herefter sam- } \\
\text { men med de øvrige studerende over } \\
\text { disse. Den interviewede studerende } \\
\text { sidder med ryggen til og noterer de } \\
\text { tanker, som falder vedkommende } \\
\text { ind, mens han/hun lytter til vejlede- } \\
\text { rens og de medstuderendes refor- } \\
\text { muleringer og forståelser af det, } \\
\text { som han/hun har sagt. }\end{array}$ \\
\hline $\begin{array}{l}\text { Videns- } \\
\text { omsætning: } \\
\text { fra vejledning } \\
\text { til opgave- } \\
\text { skrivning } \\
30 \text { min. }\end{array}$ & $\begin{array}{l}\text { Individuelt arbejde } \\
\text { De studerende arbej- } \\
\text { der med at skrive } \\
\text { deres tekster om ud } \\
\text { fra de råd de har fået }\end{array}$ & $\begin{array}{l}\text { Tremandsgrupper } \\
\text { De studerende udar- } \\
\text { bejder i fællesskab en } \\
\text { liste over fem ting, } \\
\text { som de har lært i } \\
\text { vejledningen, og som } \\
\text { de kan bruge i opga- } \\
\text { veskrivningen }\end{array}$ & \\
\hline $\begin{array}{l}\text { Afslutning: } \\
15 \text { min ca. }\end{array}$ & $\begin{array}{l}\text { Runde med svar på } \\
\text { spørgsmålet: Hvad } \\
\text { er mit næste skridt? }\end{array}$ & $\begin{array}{l}\text { Aftaler omkring } \\
\text { peer- } \\
\text { feedback/samarbejde } \\
\text { til næste gang }\end{array}$ & $\begin{array}{l}\text { Runde med svar på spørgsmålet: } \\
\text { Hvad har jeg lært i dag ift. det, som } \\
\text { vi har talt om i vejledningen? }\end{array}$ \\
\hline
\end{tabular}




\section{Det virtuelle vejledningsrum}

\section{Blackboard (BB)}

BB inddrages aktivt i projektet. Vi har på BB fået oprettet en organisation med titlen Kollektiv Akademisk Vejledning (KAV), og det er vores ambition, at dette skal være en aktiv og dynamisk platform for kommunikation på kryds og tværs mellem vejledere og studerende. KAV platformen er for nu oprettet med de kategorier/mapper, der er beskrevet $\mathrm{i}$ nedenstående skema, men den er tænkt som en dynamisk platform, hvor flere relevante kategorier kan tilføjes, efterhånden som nye ideer og behov melder sig. Platformen er et vejledningsrum med mange innovationsmuligheder, og vi håber, at projektet kan bidrage til, at den side af vejledningen kvalificeres.

\begin{tabular}{|c|c|}
\hline Værktøjskasse & Dokumenter fra inspirationskataloget \\
\hline Rammer for vejledning & $\begin{array}{l}\text { Undervisningsplaner og planer for vejledning for hvert enkelt for- } \\
\text { løb, som de deltagende vejledere er tilknyttet }\end{array}$ \\
\hline Vejledningsgrupper & $\begin{array}{l}\text { Her findes en mappe til hver af vejledningsgrupper, som de delta- } \\
\text { gende vejledere er tilknyttet. }\end{array}$ \\
\hline Q\&A Spørgekasse & $\begin{array}{l}\text { Åbent rum, hvor studerende løbende i deres skriveproces kan stille } \\
\text { spørgsmål af generel karakter og med relevans for flere studerende } \\
\text { til deres vejleder. Både spørgsmål og svar kan ses af alle deltagere. }\end{array}$ \\
\hline Evaluering & $\begin{array}{l}\text { Her kan vejledere undervejs i projektet dele deres erfaringer, ud- } \\
\text { fordringer og succeshistorier med hinanden - ligesom studerende } \\
\text { dele deres oplevelser med at modtage KAV. }\end{array}$ \\
\hline Nyheder & $\begin{array}{l}\text { Vi vil i projektgruppen opdatere KAV-platformen med al relevant } \\
\text { information om projektets udvikling. }\end{array}$ \\
\hline
\end{tabular}

\section{Vejledning pr. mail}

I den måde, som vi indtil har praktiseret KAV på, har vi tilbudt den sidste vejledning i forløbet (nr. 4) som en mailvejledning. Den enkelte vejleder sætter selv rammen for indholdet til denne vejledning. Oftest er fokus et uddrag af analyse og et udkast til 
diskussion, men det afhænger af, hvor langt den studerende er nået i processen. Herudover svarer vejlederen kun på korte og afklarende spørgsmål pr. mail.

\section{Arbejde med peer-feedback}

Arbejdet med peer-øvelser og peer-feedback er en af hjørnestenene i KAV. I inspirationskataloget beskriver vi forskellige øvelser, som vejlederen kan benytte sig af i dette arbejde. En god idé kan være at starte med par-øvelser - og dernæst en øvelse, hvor to par mødes for herefter at arbejde med triader eller større grupper. Det er vores erfaring, at det giver mest udbytte i starten af et vejledningsforløb, da det kræver mere øvelse og fokusering at holde det faglige fokus i en større gruppe. I arbejdet med at skabe rammer for konstruktiv feedback må man som vejleder overveje følgende (Rienicker \& Bruun, 2013, s. 263):

- Hvad og hvor meget skal der gives feedback på

- Hvilke kriterier skal anvendes i feedbacken

- Hvordan skal disse kriterier opstilles - og af hvem? Laves de i et samarbejde med de studerende - eller er det vejlederen, som opstiller dem? Og hvorfor?

- Hvem skal give feedback - og hvorfor?

Inspirationskataloget giver forslag til, hvordan de studerende kan coache og give hinanden feedback. Men det er også et område, som vi ønsker at arbejde med at kvalificere i udviklingsprojektet. 


\section{Udfordringer i KAV}

Som tidligere nævnt kan KAV-processen beskrives som en socialiseringsproces, hvor de studerende skal erfare og vænne sig til, at de kan opfylde undervisningens mål gennem KAV. For vejlederen er udfordringen ved den kollektive vejledning, at man skal være tydelig omkring det, som de studerende forventes at levere i processen. Denne tydelighed skal give de studerende troen på, at vejledningen er fyldestgørende i forhold til, at de når det, de skal. Jo bedre dette formidles, jo færre usikre studerende henvender sig efter en vejledningsseance er slut. I dette afsnit peger vi således på de punkter, hvor KAV kan opleves som en udfordring - både fra vejlederens og de studerendes synsvinkel.

\section{Ny studiekulturer, nye roller}

De studerende kan være usikre på deres projekt, faglige og genremæssige bedømmelseskriterier, skriveprocessen samt deres faglige niveau og progression. Mange vejledere, som praktiserer KAV beskriver således, hvordan de studerende står i kø efter vejledningen for at få svar på lige netop deres spørgsmål. Sådan var det også på Master i Vejledning, da vi startede med KAV i 2009. I dag er det helt anderledes, da de studerende har fået øje for, hvordan de kan bruge hinanden - og ikke mindst - er blevet mere strukturerede i deres arbejdsproces. I starten kan deres bekymring håndteres 'pragmatisk' ved at tillade, at de sender en mail. I hovedsagen er dog det lange seje træk med et konsekvent arbejde med peer-feedback og peer-øvelser i vejledningen, som har betydet, at de studerende har fået øje på, hvor meget de kan bruge hinanden til såvel socialt som fagligt. Men hvis man som vejleder oplever, at der er studerende, som er særligt sårbare eller fagligt svage, kan instanser som akademisk skrivecenter eller studenterrådgivningen inddraget. Som KAV-vejleder skal man være opmærksom på, at det kan være langt sværere end ved almindelig individuel vejledning tidligt at spotte de elever, der i særlig grad har brug for ekstra hjælp i skriveprocessen for at komme i mål til sidst. Det er derfor vigtigt, at man tilrettelægger vejledningen sådan, at man tidligt i vejledningsforløbet får tilsendt tekst fra alle studerende. 


\section{Modstand mod KAV}

\section{Den studerende ønsker ikke at deltage i/møder ikke op til vejledning}

Der kan være flere strategier ift. at håndtere denne situation

- Vejleder kan notere sig dette og tage kontakt til de studerende og få indsigt i, hvad der har forårsaget fraværet. Vejlederen kan sammen med den studerende evt. lægge en plan for, hvordan den studerende kan deltage/ikke deltage i vejledningen på en konstruktiv måde.

- Vejleder kan notere det, men fokusere på det, som fungerer i vejledningen/ og/eller undlade at kontakte den studerende.

\section{Skriveprocessen: De studerende afleverer ikke deres oplœg til tiden}

I KAV kan det være en udfordring af skabe kvalitet i skriveprocessen og de studerendes tekster, da det beror på, at alle studerende deltager aktivt i den - og deltager aktivt $i$ at give feedback til medstuderende (Dysthe, 2001). Den skriftlige del af KAV-forløbet er derfor et centralt fokus i udviklingsprojektet. Skriveprocessen må nødvendigvis udvikles i relation til undervisningen, så de studerende i vejledningen stilladseres $i$ at producere viden i overensstemmelse med de forskningstraditioner, som er repræsenteret i fagets pensum. Progressionen i KAV-vejledningerne følger de forskellige af de afsnit, som indgår i akademiske eksamensopgaver. Vejlederen kan benytte sig af forskellige strategier, hvis de studerende ikke overholder deadline for at fremsende materiale eller læse/give feedback på medstuderendes oplæg.

1. Den studerende, som ikke har afleveret rettidigt, vejledes ikke.

2. Den studerende kan deltage i vejledningen som en 'flue på væggen', men vejlederen forholder sig ikke særligt til det, som er denne studerendes te$\mathrm{ma} /$ problemstilling.

3. Den studerende deltager i vejledningen og dialogerne på lige for med de andre studerende.

Uanset hvilken model, vejlederen vælger at følge, er det en god idé at melde det ud inden vejledningen starter. På denne måde kan problemet måske forebygges.

\section{De studerende er forskellige steder i skriveprocessen}

Som semestret skrider frem ser man ofte, at de studerende har vidt forskellige måder og tempi at bevæge sig gennem skriveprocessen på. Denne forskel er tydeligst til den sidste vejledning, hvor nogle studerende har skrevet udkast til analyse, mens andre 
ikke er gået i gang med den endnu. Øvelsen i KAV-processen er tydeliggøre, at de studerende deltager med afsæt i de erfaringer, de har gjort sig med at skrive, og at deres styrker og svagheder derfor vil være af forskellig karakter. Det er vigtigt, at alle i gruppen oplever, at de både får hjælp og hjælper andre, således at alle får en position som kompetent deltager i KAV-gruppen. Etableringen af en sådan fællesforståelse og gensidig respekt er afgørende for deltagernes tiltro til og udbytte af peer feedback og erfaringsdeling. For at alle i gruppen får noget med sig fra hver vejledningsgang, er det vigtigt at vejlederen faciliterer vejledningsprocessen så forskellige typer af studerende får mulighed for at deltage med forskellige perspektiver på det tema, som er i spil i vejledningen. Dvs. at stimulere en frugtbar samspil mellem de studerende, som er hurtige til at omsætte vejledning til praksis og sender tekster til hver vejledningssession, og de studerende, som har svært ved at komme i gang, og som føler usikkerhed i skriveprocessen og ift. de forventninger, der skal indfries til eksamen. En måde at takle denne udfordring på, kan være at parre studerende, så de arbejder sammen med en, der oplever de samme typer af udfordringer, som dem selv - eller at mikse grupper, hvor begge typer af studerende er repræsenteret. Det er dog en vigtigt pointe, af KAV ikke er tænkt som en platform, hvor de fagligt stærke studerende vejleder de mindre fagligt stærke. Det er tænkt som en vejledningsform, der stilladserer de studerendes udvikling som studerende, medvejledere og opgaveskrivere. I processen med at få alle studerende godt i gang med at skrive kan det være en god idé at invitere akademisk skrivecenter til den første vejledning, så de studerende får en viden om, hvordan de kan støtte dem i skriveprocessen. Herefter kan det være enklere at henvise de studerende som ikke er kommet i gang med at skrive til akademisk skrivecenter.

\section{Facilitator eller ekspert? At involvere medstuderende eller komme med et svar}

I vores artikel fra 2015 (Wichmann-Hansen et al., 2015) peger vi på udfordringen i at håndtere en heterogen gruppe af studerende. Ambitionen om at være facilitator og fødselshjælper for de studerendes erkendelsesprocesser kan let vige for den vante ekspertrolle, som også er nødvendig og vigtig at påtage sig, når forholdet mellem produkt og proces skal balanceres. Med andre ord er vejlederens professionelle opgave (og udfordring) at sikre sig, at processerne i det kollektive vejledningsrum bidrager til at give de studerende et kvalificeret analytisk blik, så de kan skrive en opgave, som opfylder de akademiske standarder. Spørgsmålet er således, hvordan man kan pendle mellem at være ekspert og facilitator? (Wichmann-Hansen et al., 2015). Jo mere bevidst vejlederen er om dialogens dynamik i et kollektivt forum, jo bedre vil hun kunne afgø- 
re, hvordan det er relevant at respondere i den konkrete situation - og det kræver forberedelse.

Ib Ravn har skrevet en del om facilitering af møder, som kan overføres til KAV². Roland Christensen (Christensen, 1991) er også god at læse. Han beskriver facilitering som "øjeblikkets kunst", når vejlederen skal vælge om hun vil besvare et spørgsmål eller åbne for en dialog om det emne, som den studerende introducerer, og dermed involvere de medstuderende. Dette dilemma er også synligt og uddybes i vores artikel om KAV fra 2015. Christensens (1991) artikel giver et systematisk overblik over en række muligheder for respons og er derfor god at læse for at få inspiration ift. at håndtere denne problematik. Vores forskning viser desuden, at en væsentlig del af vejledningen er, at vejlederen arbejder med at blive bevidst om sine egne bedømmelseskriterier for, hvornår en studerendes arbejde er godt eller dårligt. At reflektere over egne forforståelser skaber grobund for at kunne møde forskellige typer af studerende og være åben over for de problemer, som de bringer i spil i KAV (Ulriksen, 2009).

\section{Balancen mellem indhold og proces i vejledningen}

En klassisk udfordring i en kollektiv vejledningsproces er at skabe en synergi mellem indhold og proces i vejledningen. Det er ikke ualmindeligt, at studerende vil efterspørge mere "substans" i vejledningen og måske ikke har den store tålmodighed ift. at deltage i forskellige dialogiske processer, som KAV lægger op til. Derfor er det centralt, at vejlederen kommunikerer, hvad hun forventer af de studerende og ikke mindst, hvad de kan forvente af hende. Vejlederen er ikke et orakel, som er sat i verden for at besvare alle de studerendes spørgsmål. Som tidligere nævnt, lægger en KAV proces lægger op til, at de studerende tager mere ansvar for deres egen læring, hvilket betyder, at de må deltage aktivt i vejledningsprocessen for at få det fulde udbytte af den. Nedenfor har vi skitseret fire muligheder, som hver især repræsenterer forskellige bud på, hvordan forholdet mellem vejlederens input og styring - og de studerendes deltagelse kan udformes. Med andre ord kan disse 4 former også ses at være 4 forskellige bud på, hvordan forholdet mellem indhold og proces kan omsættes i vejledningen (Westmark, Nissen, Offenberg, \& Lund-Jacobsen, 2012).

${ }^{2}$ Læse mere ved at følge dette link http://studerende.au.dk/fileadmin/user upload/Ravn Bedre mder gennem facilitering.pdf. 
$\begin{array}{ll}26 & \text { KOLLEKTIV AKADEMISK VEJLEDNING } \\ & - \text { EN INTRODUKTION }\end{array}$

\begin{tabular}{|lll|}
\hline $\begin{array}{l}\text { Proces/indhold } \\
\begin{array}{l}\text { De studerende } \\
\text { har indflydel- } \\
\text { se på styring }\end{array}\end{array}$ & $\begin{array}{l}\text { Dejlederne har planlagt en dialogisk } \\
\text { proces med strukturerede kommuni- } \\
\text { kations former: Runder, interview, } \\
\text { reflekterende team }\end{array}$ & $\begin{array}{l}\text { Vejlederen er kommet med et } \\
\text { fagligt oplæg/input og har } \\
\text { planlagt en dialogisk proces } \\
\text { efter oplægget. }\end{array}$ \\
\hline $\begin{array}{l}\text { De studeren- } \\
\text { de har ikke } \\
\text { indflydelse } \\
\text { på styring }\end{array}$ & $\begin{array}{l}\text { Vejlederen lader de studerendes } \\
\text { spørgsmål og behov styre processen. }\end{array}$ & $\begin{array}{l}\text { Vejlederen kommer med et } \\
\text { fagligt oplæg input, men har } \\
\text { ikke planlagt en opfølgning. }\end{array}$ \\
\hline
\end{tabular}

\section{Fagligt svage og/eller stcrke studerende}

I de artikler, som vi har publiceret om KAV stiller vi spørgsmålet: Hvem tilgodeser KAV? De Stærke eller de svage studerende? Og endvidere, hvordan vejlederen kan spotte disse studerende? Nedenstående er forslag og overvejelser ift. denne centrale problematik, som projektet om KAV skal bidrage til at skabe mere viden omkring. Vejlederen kan:

- bede om de studerendes opsummeringer i slutningen af vejledningen af det, som de vil arbejde videre med frem mod næste vejledning - ift. de forskellige faser i processen.

- læse stikprøver ift. mistanke om evt. svage/stærke studerende og tilbyde disse individuel vejledning.

- bruge denne viden i sammensætningen af grupper i KAV (man kan her vælge at sammensætte blandende grupper med både stærke og svage studerende og evt. danne særlige grupper for de studerende, man vurderer, får brug for ekstra hjælp for at nå i mål med eksamensopgaven).

\section{Sårbare studerende}

Uanset om der er sårbare studerende, som har personlige/psykiske udfordringer, eller ej i Vejledningsforløbet, er det en god idé at informere alle studerende om de ressourcer, som universitetet tilbyder - herunder muligheden for at tage kontakt til studenterrådgivningen eller akademisk skrivecenter. Hvis det influerer på deres skriveproces, kan vejlederen evt. opfordre dem til at informere ham/hende om det. 


\section{Individuel fremlœggelse i kollektivt forum}

Den studerende kan føle sig presset/stresset over at skulle fremlægge i et kollektivt forum. I vejledningen kan vejlederen nævne denne problematik og således begrunde, at de studerende øver sig på fremlægning parvis, og herefter i mindre grupper inden de evt. fremlægger en problemstilling i det store forum. På denne måde bliver KAV også et værksted, hvor de studerende arbejder med at kvalificere deres mundtlige dialoger og argumentation.

\section{Hvordan vurderes kvaliteten/udbyttet af KAV undervejs i vejled- ningsforløbet?}

Det er en didaktisk udfordring at vurdere, hvad de studerende får ud af KAV-forløbet, før de afleverer (et skriftligt produkt) og går til eksamen. Vi har arbejdet med at bruge rammesætningen som en lakmusprøve på de studerendes udbytte:

- I starten af vejledningen beder vi (som nævnt) de studerende formulere: Hvad ønsker du at blive klogere på i denne vejledning? Eller: Når du er gået ud af døren, hvad har du så fået med dig/svar på i dag? Vejlederen skriver disse spørgsmål ned på white board og bruger dem ift. at formulere meget konkrete læringsmål for hver vejledningssession. Første vejledningsgang kunne det f.eks. være: 1) at lære hvad det sige at formulere fagligt forsvarlige og opgaveegnede problemformuleringer samt 2) at lære hvordan man formulerer sådanne problemformuleringer som del af et indledningskapitel (se inspirationskataloget).

- Afslutningsvis vender vi tilbage til de indledende spørgsmål og beder de studerende kommentere på deres udbytte af vejledningen. Derudover spørger vi hver enkelt studerende: Hvad vil du arbejde videre med inden den næste vejledning ift. det, som vi har talt om i vejledningen $i$ dag? Og mere konkret: Hvad er det forst du vil tage fat på, når du kommer hjem?

Imellem disse to spørgsmål ligger kimen til at få indsigt i, i hvilken grad den kollektive vejledning har flyttet den studerende fagligt. Som tidligere nævnt kan vejlederen evt. bede de studerende skrive svarene på disse spørgsmål ned i fx en non-stop-skriveøvelse (se inspirationskataloget) - før og efter vejledningen - og aflevere dem til vejlederen. 


\section{Anbefalinger}

Som afslutning på denne introduktion kommer vi med nogle anbefalinger i stikordsform:

- Det er en god idé at integrere vejledningen med og skema-sætte den ift. øvrige læringsaktiviteter

- 4-10 studerende pr. gruppe

- Spar med dine kolleger før, under og efter vejledningen. Det styrker dig og din vejledning.

- Tydelig formidling om hvad KAV er, og hvad der forventes af de studerende både før/under/efter-vejledningen - både skriftligt og mundtligt.

- Skabe en tydelig progression og sammenhæng mellem peer-feed-back og den prøveform, der er på modulet.

- Brug whiteboard og/eller tavle og/eller flip-over til at skabe en rød tråd i dialogerne i vejledningen.

- Lav dine egne ritualer ift., hvordan du praktiserer KAV - dvs. hvordan du organiserer vejledningsrummet. Det skaber tryghed og genkendelighed hos de studerende.

- Inddrag eksemplariske tekster, tidl. og nuværende studerende og deres opgaver i vejledningen og undervisningen.

- Som afslutning på vejledningen er det frugtbart, at hver enkelt studerende er klar over præcis, hvad hun vil arbejde med indtil næste vejledning, og har formuleret dette på skrift.

- Udvikling af gode spørgsmål i KAV-dialogerne skaber bedre opgaver. Derfor er det godt at arbejde med at kvalificere de studerendes spørgsmål i en synergi med at finde frem til akademiske måder at besvare spørgsmålene på. Nye svar skaber nye spørgsmål - eller kvalificerer de spørgsmål, som oprindeligt blev stillet. 


\section{Litteratur}

Andersen, H. L., \& Bager, T. (2011). Kollegial Supervision som udviklingsredskab i undervisningskulturer. Aarhus: Aarhus Universitetsforlag.

Bakhtin, M. M. (1981). The dialogic imagination: Four essays by M. M. Bakhtin. Austin, Texas: University of Texas Press.

Christensen, C. R. (1991). The Discussion Teacher in Action: Questioning, Listening and Response. In C. R. Christensen, David A. Garvin, Ann Sweet (Ed.), Education for Judgement. The Artistry of Discussion Leadership. (pp. 153-171). Boston: Havard Business School Press.

Dalgaard, L. G., Johannsen, L. V., Kristiansen, M., \& Bloch-Poulsen, J. (2014). Differences as a potential vehicle of organizational development? - co-researching-on-action. In M. Kristiansen \& J. Bloch-Poulsen (Eds.), Participation and power in participatory research and action research. Aalborg: Aalborg University Press.

Devitt, A. J. (1997). Genre as Language Standard. In W. Bishop \& H. Ostrom (Eds.), Genre and Writing. Issues, Arguments, Alternatives (pp. 45-55). Portsmounth: Boyton/Cook.

Devitt, A. J. (2004). Writing Genres. Carbondale: Southern Illinois University Press.

Dysthe, O. (2001). Skrive for at lære. Copenhagen, Denmark: Klim.

Dysthe, O. (2003). Dialog, samspil og laring. Århus: Forlaget Klim.

Dysthe, O., Samara, A., \& Westheim, K. (2006). Multivoiced supervision of master's students: a case study of alternative supervision practices in higher education. Studies in Higher Education, 31 (3), 299-318.

Hyland, K. (2003). Genre-based pedagogies: A social response to proces. Journal of Second Language Writing,, 17(29).

Hyland, K. (2009). Teaching and Researching Writing. Harlow: Pearson Education Limited.

Igland, M.-A., \& Dysthe, O. (2003). Mikhail Bakhtin og sociokulturel teori. In O. Dysthe (Ed.), Dialog, samspil og læring (pp. 109-124). Århus: Forlaget Klim. 
Jensen, H. N. (2015). Opgave- og skrivevejledning i klynger. København: Samfundslitteratur.

Lauvås, P., \& Handal, G. (2006). Vejledning og praksisteori. (Guidance and practice theory). Århus Forlaget Klim.

Lave, J., \& Wenger, E. (1991). Situated learning, legitimate peripheral participation. New York: Cambridge University Press.

Lillejord, S., \& Dysthe, O. (2008). Productive learning spaces - a theoretical discussion based on two cases. Journal of Education and Work, 21(1), 75-89. doi:10.1080/13639080801957154

Nordentoft, H. M. (2011). Sundhedsfaglig supervision som klinisk metode. In M. Holen, L. Sørensen, \& J. Voigt (Eds.), Kliniske metoder i sygeplejepraksis (pp. 171-187). København: Munksgaards Forlag

Nordentoft, H. M. (2012). Kollegiale vejledningsformer og læring i sundhedsarbejdet. In V. Simovska \& J. M. Jensen (Eds.), Sundhedspædagogik i sundhedsfremme (pp. 213-229). København: Gads Forlag.

Nordentoft, H. M., Thomsen, R., \& Wichmann-Hansen, G. (2013). Collective academic supervision: a model for participation and learning in higher education. Higher Education, 65(5), 581-593.

Nordentoft, H. M., \& Wistoft, K. (2012). Collaborative learning in school health nursing. Health Education, 112(5), 448 - 464. doi:10.1108/09654281211253452

Perregaard, B. (2002). Forskning og undervisning i skriftsprog. København: Akademisk Forlag.

Rienicker, L., \& Bruun, J. (2013). Feedback. In L. Rienecker , P. S. Jørgensen, J. Dolin, \& G. H. Ingerslev (Eds.), Universitetspædaogik (pp. 259-279). København: Samfundslitteratur.

Swales, J. M. (2004). Research Genres: Explorations and Applications. Cambridge: Cambridge University Press

Swales, J. M. (2008). Genre Analysis: English in Academic and Research Settings (1990). Cambridge: Cambridge University Press.

Thomsen, R., Boelskifte Skovhus, R., \& Buhl, R. (2013). At vejlede i frllesskaber og grupper. København: Schultz. 
Thomsen, R., \& Nordentoft, H. M. (2012). Kollektiv Akademisk Vejledning - et bud på en ændret organisering af vejledningen på universitetet. Dansk Universitetspædagogisk Tidsskrift, 7(12), 106 - 116.

Ulriksen, L. (2009). The implied student. Studies in Higher Education, 34(5), 517-532. doi:10.1080/03075070802597135

Vygotsky, L. (1978). Mind in society: The development of higher psychological processes. Cambridge: Harvard University Press.

Westmark, T., Nissen, D., Offenberg, L., \& Lund-Jacobsen, D. (2012). Konsulent - men hvordan? København: Akademisk Forlag.

Wichmann-Hansen, G., Thomsen, R., \& Nordentoft, H. M. (2015). Challenges in Collective Academic Supervision: supervisors' experiences from a Master Programme in Guidance and Counselling. Higher Education, 70, 19 - 33. doi:DOI 10.1007/s10734-0149821-2 
32

\section{Inspirationskatalog til Kollektiv Akademisk Vejledning}




\section{Brug af inspirations-kataloget}

Inspirations-kataloget består af en række forskellige dokumenter, hvor som rummer forslag til, som hvordan man som vejleder kan introducere til og organisere KAV. Nogle af dokumenterne har vi har udviklet i forbindelse med KAV - andre er nye bud på, hvordan man kan arbejde med de studerendes skriveproces. Vi tænker, som tidligere nævnt, at dette katalog vil vokse i løbet af projektfasen, hvor vi jo kan udveksle idéer til, hvordan KAV kan praktiseres. Desuden henviser vi til den virtuelle studiemetro på AUs hjemmeside http://studiemetro.au.dk/omstudiemetroen/

\section{Forberedelse til vejledningen}

- Vejlederbrev - en introduktion til KAV: En kort beskrivelse til KAV til de studerende med beskrivelse af, hvordan de kan forberede sig til KAV.

- Gruppedannelse: Et bud på, hoordan man kan facilitere en gruppedannelsesproces.

\section{Organisering af vejledningsrummet, skriveprocessen og eksamen}

- Stilladsering af akademisk skrivning: En beskrivelse af, hvordan det skriftlige akademiske arbejde styrkes $i$ vejledningen.

- Tips til modul 1 opgaven: Eksempel på en manual til opgaveskrivning og, hvordan de studerende kan arbejde med de forskellige afsnit i en opgave.

- Dagsordener til KAV: Eksempler på, hvordan vejledningen kan organiseres.

- Tips til masterprojekteksamen: Et eksempel på, hvordan eksamen kan introduceres skriftligt.

- Non-stop-skriveøvelse: En skriveøvelse som kan bruges i og som opsamling på/evaluering ift. vejledningen

\section{Organisering af peer-dialoger}

- Opponentfunktion

- Par-øvelser

- Triade-øvelser

- Reflekterende team

- Det engelske parlament

- WIP: Work-in-progress seminar

- Café-modellen: Anerkendende feedback i projektgrupper 
34 KOLLEKTIV AKADEMISK VEJLEDNING

FORBEREDELSE TIL VEJLEDNINGEN

\section{Forberedelse til vejledningen}




\section{Introduktion til Kollektiv Akademisk Vejledning}

Nedenfor giver vi et eksempel på, hwordan man kan introducere til et forløb med Kollektiv Akademisk Vejledning - herunder rammer og deadlines i vejledningsforløbet.

\section{Navn på modul - Efterår/forår - årstal}

Vejledningen på modulet er tilrettelagt som Kollektiv Akademisk Vejledning (KAV). Formålet med KAV er at introducere en kollektiv akademisk arbejdsform via vejledning, hvor studerende får erfaringer med at præsentere og diskutere faglige spørgsmål i et kollektivt forum - både skriftligt og mundtligt. Formen giver mulighed for at du får faglige input til deres videre proces - gennem kvalificerede spørgsmål, litteraturhenvisninger og sparring med både din vejleder og medstuderende.

Endelig er det vores erfaring at studiemotivationen og skrivelysten øges.

Der er 3 datoer for den kollektive akademiske vejledning. Der vil være 4 til 5 studerende pr. gruppe. I de papirer du sender til vejledningen skal du hver gang formulere dine ønsker om respons/feedback og evt. spørgsmål til både underviser og evt. de andre medlemmer i gruppen.

\section{Problemformuleringsseminar dato}

Send motivation for emnevalg og et forslag til en problemformulering. På seminaret udveksler og arbejder vi med forslag til problemformuleringerne og indhold i modulopgaverne. Målet er at gå fra vejledningssessionen med en foreløbig køreplan for det videre arbejde med modulopgaven.

\section{2. vejledning dato}

- Send en foreløbig disposition for opgaven med stikord til indhold i de forskellige afsnit. Du kan evt. sende et udvalgt afsnit til respons.

\section{3. vejledning dato}

- Til dette seminar skal du helst sende et eks. på din analyse. Der skal som minimum sendes problemformulering, uddybning af hvordan denne skal undersøges 
36 KOLLEKTIV AKADEMISK VEJLEDNING

INTRODUKTION TIL KOLLEKTIV AKADEMISK VEJLEDNING

forslag til en kommenteret indholdsfortegnelse, hvor der står, hvad de forskellige afsnit skal indeholde plus en litteraturliste.

\section{Forberedelse til vejledningen}

Senest 4 arbejdsdage før vejledningen skal du lægge dit oplæg til vejledningen på vejledningsgruppens forum på Blackboard. Forud for vejledningen læses de medstuderendes oplæg.

\section{Sted og tid}

Meddeles af vejleder via Blackboard.

\section{Hvordan foregår Kollektiv Akademisk Vejledning?}

KAV veksler plenum seancer og samtaler med sidemanden om de fremsendte tekster. Formen inviterer til, at du kvalificerer din akademiske argumentation - både mundtligt og skriftligt gennem dialoger med og respons fra både vejlederen og dine medstuderende.

\section{Vejlederne på modulet}

Her skrives navn og mailadresse på vejlederne

\section{Tidsplan og deadlines på modulet}

Her skrives de vigtigste tider

\section{Aflevering af opgaven:}

\section{Eksamen:}




\section{Gruppedannelse}

Hvis man vejleder en større gruppe studerende kan det være en god idé at bruge en del tid på gruppedannelsesprocessen, da det kan danne grobund for at klart fokus $i$ opgaven - og en god samarbejdsproces mellem de studerende, da det er tydeligt allerede fra starten, hoad de skal arbejde henimod. Afhængigt af antallet af studerende kan den faciliteres af enten en eller to facilitatorer som også er vejledere på modulet. De studerende arbejder selvstændigt en stor del af tiden - tiden er organiseret og planlagt så de forbereder sig ift. at vejleder/ne på modulet er til rådighed på bestemte tidspunkter. Processen fordrer, at man har gennemtænkt logistikken inden det hele går $i$ gang - så der dels er mulighed for at samles $i$ stor plenum - i et auditorium - og dels at der er mindre lokaler til rådighed.

\section{Eksempel på 4 dages introduktionsprogram/gruppedannelses- proces}

Velkommen til en lille intens uge, som sikrer, at alle kan komme godt fra start.

Mandag

$09.30-11.00$

\section{kl. 9.30-16.00 - i: lokale}

Velkommen til modulet - om dagens og ugens program Introduktion til kravene på modulet ved uddannelseskoordinator Fortællinger om læring fra projekter på modulet: Tidligere grupper fortæller om deres projekter.

Kort om: studievejledning, projektforum, praktik mv.

11.15 - 12.15 Intro til ideer, temaer, lyster i forbindelse med forårets projektarbejde.

13.00-13.45 De første projekt-ideer i forbindelse med efterårets projektarbejde.

14.00-15.00 Kursuspræsentationer fra modulet

Tirsdag $\quad 9.30-13.00$ og 13.00-15.30 i: lokale

$9.30-11.00 \quad$ Ide-udvikling og begyndende gruppedannelse

11.00-12.00 Opsamling: Hvilke projekter er i spil?

\section{Onsdag $\quad 9.30-15.00$ i: lokale}

09.30 - 10.30 Forberedelse til møde med projektvejleder/e

10.30 - 12.30 Projektkvalificering med deltagelse af vejledere

$13.00-15.00$ Fortsat arbejde med projektet og besøg på biblioteket 
Torsdag $\quad 9.30-15.00$ i: lokale

09.30-10.00 Opsamling: Hvilke projekter er i spil?

10.00-12.00 Forberedelse til møde med projektvejleder/e

12.00-13.30 Frokost og karrieremesse med deltagelse af studievejledere

13.30-14.45 Projektkvalificering med deltagelse af vejleder/e

14.45-15.00 Evaluering af projektforløbet og opsamling på løse ender...

\section{Beskrivelse af den indledende fase i gruppedannelsesprocessen}

(kan fx finde sted mandag/tirsdag i planen på side 1)

\section{Opvarmning: "Cocktailparty"}

De studerende får udleveret forslag til indledende spørgsmål. Dernæst går de rundt mellem hinanden og stiller hinanden spørgsmål - så som:

- Hvad skrev du projekt om sidste semester?

- Hvad er du særligt optaget af lige nu?

- Hvilke teorier/metoder har du prøvet at arbejde med?

- Hvad er det vigtigste du lærte sidste semester?

Ind imellem klapper facilitator i hænderne for at markere, at der nu skal skiftes samtalepartner.

Efter 20-30 min - alt efter temperament - sætter de studerende sig ved bordene i rummet.

Samtaler ved borde om projektideer

- Alle borde skal producere mindst 2 ideer pr person

\section{Ideerne grupperes af facilitatorerne;}

- Hvad handler om børn og læring, organisation, inklusion osv...

- Ideerne samles og bordene får nu "navne" ift. de overordnede tematikker

\section{2 nye runder}

- De studerende sætter sig nu ved det bord, de er interesserede i og snakker med de andre, efter $1 / 2$ time (hvor man skal blive siddende), kan man gå til næste bord.

Alle projekter, som nogen arbejder med op på tavlen (med e-mail på idebcerer)

- Efter endnu $1 \frac{1}{2}$ time kan man gå til et tredje bord, tilbage til 1. eller blive ved 2. 
Videre snak ved bordene (facilitator/er understøtter)

Vejleder/e cirkulerer ved bordene i en time

Videre arbejde, igen fælles runde om, hvilke projekter, der er i spil, nogle streges fra tavlen, andre skrives på og der skrives medlemsantal og evt. hvis gruppen er lukket.

Der arbejdes videre ved bordene (og vejledere kommer igen på runde)

Afrunding: Alle i gruppe eller er der hængepartier??? 
40 KOLLEKTIV AKADEMISK VEJLEDNING

ORGANISERING AF VEJLEDNINGSRUMMET,

SKRIVEPROCESSEN OG EKSAMEN

\section{Organisering af vejlednings- rummet, skriveprocessen og eksamen}




\section{Stilladsering af akademisk skrivning}

I dette dokument giver forslag til, hvordan vejleder kan fä de studerende godt i gang med og bygge vejledningsseancer op omkring skriveprocessen. Med andre ord adresserer vi, hvordan de mundtlige dialoger vejledningen kan forbindes med de studerendes skrivning så den akademiske tankegang, struktur og argumentation kvalificeres i opgaverne.

\section{Indledende overvejelser ift. at skabe et trygt vejledningsrum}

Klare rammer for den feedback, som den studerende modtager i vejledningsforløbet, er en forudsætning for, at vejledningsrummet kan opleves som trygt og givende. Derfor er det godt, hvis vejlederen allerede første vejledningsgang kridter spillereglerne for samarbejdet i gruppen op ved at adressere følgende:

- Det kan være udfordrende at dele og give hinanden feedback på tekster, som man måske har arbejdet intensivt med. Gruppen må derfor forhandle i hvilken grad møderne og det, som der gives feedback på er fortroligt. Gensidig tillid og respekt kan evt. understøttes af en teambuilding-øvelse.

- KAV kan betragtes som et laboratorium, hvor der kan eksperimenteres i fællesskab. Der er ingen dumme spørgsmål, ingen forkerte svar og ingen svar, som ikke kan forbedres og videreudvikles.

- Alle deltager med tekster efter aftale (dette er en forudsætning for et solidt læringsudbytte).

- I KAV er opmærksomheden ikke rettet mod egne og andres fejl, men mod læring. Som en del af KAV lærer de studerende at give konstruktiv feedback på en måde, der stilladserer de studerendes videreudvikling af skrivekompetencer med afsæt i de 3 K'er (Jensen, 2015). Det betyder at kritikken skal være

○ Kærlig, dvs. at den, som giver feedback må sætte sig i den andens sted og forstå, hvor skriveren vil hen og fortæller skriveren: Hvad jeg godt lide i oplægget og hvorfor med afsæt i konkrete eksempler.

- Konstruktiv ved at fortælle skriveren: Hvad vil jeg gerne læse mere om og hvorfor?

○ Kritisk ved at besvare spørgsmålet: Hvad kan jeg ikke forstå i oplægget og hvorfor? 
- Den største udfordring ved at få feedback kan være bare at lytte og modtage den, og dernæst at huske den bagefter. Derfor kan skriveren, som skal modtage feedback vælge at alliere sig med en medstuderende, som tager referat af feedbacken så skriveren kan koncentrere sig om at lytte - og bare at lytte.

- Skrivning er ikke kun en personlig proces, men også et håndværk man kan lære at mestre ved at imitere strukturen i andres tekster og få indsigt i normerne for den genre, man er i gang med at tilegne sig. At lære den akademiske genre at kende er at lære at tænke, argumentere og strukturere i overensstemmelse med normer, der er udviklet i en akademisk kontekst.

\section{Imitatio}

Et grundlæggende princip i vejledningen af skriftlige opgaver er at arbejde med afsæt i Imitatio, som er en klassisk retorisk læringsstrategi. Imitatio betyder at efterligne, og i en skrivekontekst bruges begrebet ift. lave en analytisk afkodning af et bestemt felts diskurs og genrenormer - og ikke ift. at invitere de studerende til at lave afskrift/plagiat!! Konkret kan vejlederen arbejde med dette princip ved at inddrage fagtekster fra pensumlisten og/eller fra tidligere studerendes tekster i vejledningen. Fx kan man inddrage en nøgleartikel eller kapitel i undervisningen - eller et 12 tals speciale, som er relevant for det tema, som de studerende arbejder indenfor.

Sammen med de studerende kan vejlederen undersøge, hvorfor og hvordan disse tekster kan karakteriseres som akademiske tekster ift. den måde, som de fremstiller dels den problemstilling, som de præsenterer - dels, hvordan de arbejder med at undersøge og belyse den - teoretisk og metodisk. Formålet med denne undersøgelse er således, at præcisere, hvordan man kan strukturere en akademisk fremstilling ligesom Imitatio også kan bruges til at udskille særligt velegnede faste formuleringer, ord eller argumentationsstrukturerer med. I beskrivelsen nedenfor har vi fokus på, hvordan de studerende arbejder med strukturen i den akademiske genre, men da form og indhold ikke kan adskilles, kan dette arbejde fint gå hånd i hånd med en kvalificeret samtale om teksternes indhold. I det følgende uddyber vi, hvilke kriterier de studerende kan arbejde med i deres undersøgelser af karakteristika i centrale afsnit i en akademisk tekst.

\section{Den svœre start - indledningsafsnittet}

Mange studerende har svært ved overhovedet at få begyndt. Én ting er at formulere en problemformulering, en anden er at gøre introduktionen af denne relevant i eksa- 
mensopgavens indledende afsnit. I det følgende gives der forslag til en række handlinger, som kan ekspliciteres som relevante indledende handlinger. Oversigten er lavet med inspiration fra John M. Swales' kanoniske genrebeskrivelse af forskningsartiklen som genre (Swales, 2008, s. 137-176).

\begin{tabular}{|l|l|}
\hline $\begin{array}{l}\text { Struktur- } \\
\text { elementer }\end{array}$ & $\begin{array}{l}\text { Forslag til genrerelevante sproghandlinger i indledningsafsnit i akademiske eksamens- } \\
\text { opgaver }\end{array}$ \\
\hline $\begin{array}{l}\text { At etablere } \\
\text { et territori- } \\
\text { um }\end{array}$ & $\begin{array}{l}\text { Redegøre for hvorfor en bestemt problemstilling er relevant for en bestemt samfundsgruppe } \\
\text { eller i et bestemt økonomisk/historisk/samfundsmæssigt/videnskabeligt perspektiv. } \\
\text { og/eller } \\
\text { Generalisere ved at sammenkæde et specifikt problem med større problemstillinger } \\
\text { og/eller } \\
\text { Introducere forskning der undersøger en bestemt problemstilling }\end{array}$ \\
\hline $\begin{array}{l}\text { At etablere } \\
\text { en niche }\end{array}$ & $\begin{array}{l}\text { Sætte spørgsmålstegn ved en gængs antagelse } \\
\text { eller } \\
\text { Rejse et forskningsmæssigt nyt spørgsmål } \\
\text { eller } \\
\text { Placere opgavens problemformulering inden for en bestemt forskningstradition } \\
\text { eller } \\
\text { Udpege noget som mangler at blive afdækket i en bestemt forskningsundersøgelse }\end{array}$ \\
\hline $\begin{array}{l}\text { At indtage } \\
\text { nichen }\end{array}$ & $\begin{array}{l}\text { Redegøre for opgavens formål } \\
\text { og } \\
\text { Opsummere opgavens væsentligste resultat } \\
\text { og } \\
\text { Præsentere opgavens afsnit }\end{array}$ \\
\hline
\end{tabular}

Modellen giver mulighed for at lave strukturanalyser af indledninger i forskellige gode tekster, som vejlederen vurderer ligger tæt op ad den genre, som de studerende går til eksamen i. I vejledningen kan vejlederen fx addressere spørgsmål som: hvordan struktureres en redegørelse? Hvor meget kontekst skal der beskrives, når der generaliseres over en specifik problemstilling? Hvor deltaljeret skal en præsentation af opgavens afsnit være? 


\section{Én opgave, ét sammenhœngende argument - forslag til feedback- emner og arbejdsspørgsmål}

I skemaet nedenfor er der forslag til spørgsmål og emner, som kan behandles i arbejdet med de skriftlige opgavers øvrige strukturelementer. Ideen er som sagt at bruge fokuspunkterne som pejlemærker i analyser af gode eksempler hentet fra pensumlisten eller fra tidligere studerendes opgaver samt at anvende spørgsmålene og resultaterne fra analyserne som inspirationskilde for de studerende, når de individuelt, på tomandshånd eller i grupper arbejder med at skrive og omskrive deres egne tekster.

\begin{tabular}{|c|c|}
\hline Struktur-elementer & Træk som kan ekspliciteres, eksemplificeres og imiteres \\
\hline Teori & $\begin{array}{l}\text { Delelementer som indgår i teoriafsnit: } \\
\text { Resume af centrale undersøgelser (hvem, hvor, hvad, resultat og implikationer for } \\
\text { nærværende undersøgelse) } \\
\text { Definition af centrale begreber (evt. med eksempler) } \\
\text { Redegørelse for centrale teoretikeres erkendelser (evt. med eksempler) } \\
\text { Sammenligning af begreber/erkendelser/andres forskningsresultater } \\
\text { Eksempler på spørgsmål om sprog og argumentation i teoriafsnittet: } \\
\text { Er den præsenterede teori relevant i forhold til opgavens problemformulering? } \\
\text { Defineres og anvendes centrale begreber stringent? } \\
\text { Er de præsenterede begreber anvendelige i opgavens analyse? } \\
\text { Er antallet af præsenterede begreber passende? }\end{array}$ \\
\hline Metode & $\begin{array}{l}\text { Delelementer som ofte indgår i metodeafsnit: } \\
\text { Redegørelse for den metode som anvendes ved indsamling og udvælgelse af data- } \\
\text { materiale } \\
\text { Redegørelse for den eller de analysemetoder, der anvendes i opgaven } \\
\text { Vurdering af datamaterialets særlige træk, kvaliteter, mangler og repræsentativitet }\end{array}$ \\
\hline Analyse & $\begin{array}{l}\text { Eksempler på spørgsmål om sprog og argumentation i analyseafsnittet: } \\
\text { Præsenteres eksemplernes kontekst? } \\
\text { Gives der nok eksempler? } \\
\text { Beskrives alle relevante elementer i eksemplerne udtømmende i analysen? } \\
\text { Sammenlignes eksempler undervejs? } \\
\text { Er analysen systematisk? } \\
\text { Er der sammenhæng mellem underoverskrifter og delkonklusioner? } \\
\text { Fremhæves forbehold tydeligt sprogligt (muligvis, det kan fortolkes som, en anden } \\
\text { mulighed er, jeg foreslår at etc.). }\end{array}$ \\
\hline
\end{tabular}




\begin{tabular}{|c|c|}
\hline & $\begin{array}{l}\text { Fremhæves delkonklusioner med metasprog? (det betyder, derfor, vi kan på den } \\
\text { baggrund konkludere). }\end{array}$ \\
\hline Konklusion & $\begin{array}{l}\text { Konklusionen indeholder: } \\
\text { En opsamling af opgavens analyseresultater } \\
\text { og } \\
\text { En opsamling og vurdering af afhandlingens samlede argument } \\
\text { (forholdet mellem problemformulering, teori, metode og analyse) } \\
\text { og } \\
\text { En diskussion af evt. problemer, som er opstået undervejs i undersøgelsen } \\
\text { eller } \\
\text { En diskussion af muligheder for videre undersøgelser } \\
\text { eller } \\
\text { En perspektivering til andre undersøgelser } \\
\text { eller } \\
\text { Forslag til hvordan man kan intervenere i et bestemt felt på baggrund af under- } \\
\text { søgelsens resultater }\end{array}$ \\
\hline
\end{tabular}

\section{Hvordan kan vejledningen i en akademisk skriveproces forløbe?}

En vejledningssession kan $\mathrm{fx}$ inddeles i tre faser:

1. Tilegnelse af akademisk diskurs og genrer: Her analyseres gode eksempeltekster som hentes fra pensumlisten eller tidligere studerendes gode eksamensopgaver. Genretræk eksemplificeres som i genrebeskrivelserne ovenfor.

2. Kritisk analyse: Denne fase kræver at deltagerne har en vis erfaring med det fag, som de går til eksamen i, da eksempelteksterne analyseres med et kritisk blik gennem at de studerende forholder sig til spørgsmål fx: Er tekstens pointer formuleret klart og præcist? Kunne man have struktureret teksten bedre? Er der underlæggende præmisser i argumentationen som kan anfægtes? etc.

3. Omskrivning af deltagernes egne tekster: Dette kan foregå ved, at deltagerne giver feedback til hinanden, som vi foreslår i starten af denne tekst. Med andre ord stiller de spørgsmål til hinanden, kommenterer og skriver tekster om i fællesskab (hvis de skriver sammen i en gruppe) eller arbejder individuelt. I denne fase omsætter de studerende således den viden, som de har fået analyserne af eksempelteksterne, i deres egen skrivning. 
46 KOLLEKTIV AKADEMISK VEJLEDNING

STILLADSERING AF AKADEMISK SKRIVNING

\section{Referencer}

Jensen, H. N. (2015). Opgave- og skrivevejledning i klynger. København: Samfundslitteratur.

Swales, J. M. (2008). Genre Analysis: English in Academic and Research Settings (1990). Cambridge: Cambridge University Press. 


\section{Tips til opgaveskrivning}

Dette er et eksempel på en 'pixi-vejledning' til at skrive akademisk funderet opgave fra modul 1 på Master $i$ Vejledning. Vejledningen gennemgår vha. eksempler hoilke afsnit, opgaven skal indeholde, og hoad der skal stå $i$ de forskellige afsnit - teori, metode, analyse, diskussion, konklusion og perspektivering. Kravene til disse afsnit kan varierer afhængigt af fag og kontekst, så derfor må vejledningen blot betragtes som en inspiration - ikke som en endegyldig formel for, hvordan en sådan kan skrives.

\section{Tips til modul 1 opgaven}

Modul 1 opgaven er en 15 (normal)siders opgave, som uddyber et tema indenfor de emner, som modulet giver indsigt i. Modulet omhandler:

- Vejledningsteorier

- Karriereteorier

- Erhvervsvalgs- og udviklingsteorier

- Vejledningens filosofi og idéhistorie

- Læring og vejledning

- Etik i vejledning, herunder værdiafklaring

Med andre ord er der mange mulige vinkler indenfor vejledningsfeltet, som du kan vælge at udfolde i din opgave. Formålet med resten af denne vejledning er at beskrive, hvordan du konkret kan arbejde med netop dit tema i de forskellige afsnit, som en akademisk opgave indeholder. Tjek også studieordningen på https://mit.au.dk/EDDI/webservices/DokOrdningService.cfc?method=visGodkendtOrd $\underline{\text { ning\&dokOrdningId=2042\&sprog=da. }}$

\section{Indledende afsnit: motivation og problemformulering/formål prœ- senteres}

Motivationen kan være faglig men også personlig - det kan være, at du har haft en oplevelse, der har gjort, at du har fået interesse for et tema.

Case Måske er der er specifik case, som er repræsentativ for det problem, du gerne vil udfolde i opgaven. Den kan du evt. præsentere indledningsvis. 


\section{Afgrcensning}

Problemet kan være omfattende, og du kan derfor med fordel eksplicit redegøre for den afgrænsning, du foretager.

Ex 1: Voksenuddannelse er et stort område. Jeg vælger at fokusere på voksne, der(hvilken kontekst). Uddannelse? Hvornår? Køn? Osv.

Ex 2: Klinisk vejledning foregår mange steder. Fx XXXX. I min opgave tænker jeg på vejledere, som har XXX funktion $i \mathrm{XXX}$ kontekst

Problemformuleringen er noget, de fleste arbejder med, indtil opgaven er færdig - og det er helt ok.

Problemformuleringen består (ofte) af et overordnet spørgsmål:

1. En hvordan problemformulering lægger op til fremtidige handlinger, dvs. en handlingsorienteret problemformulering.

2. En hvorfor problemformulering lægger mere op til en forklarende opgave evt. på et teoretiserende plan.

Læs mere i

- "Den gode opgave" af Lotte Rienicker og Peter Stray Jørgensen

- "Forskning om og med mennesker" af Laila Launsø og Olaf Rieper

Det kan være en god ide at arbejde med nogle underspørgsmål, der støtter den overordnede problemformulering.

\section{Ex på problemformulering vedr. klinisk vejledning}

Hvordan kan uddannelsen af kliniske vejledere kvalificeres vejledningsteoretisk, så den kan tilgodese den praksis, kliniske vejledere møder?

- Hvad er det for kontekster, de arbejder i?

- Hvad er det for problemer/dilemmaer, den kliniske vejleder møder?

Eller:

- Hvilke udfordringer kan der være forbundet med X i et vejledningsteoretisk perspektiv?

- På hvilke måder kan vejlederen styrke sine kompetencer, så han/hun kan håndtere disse? 


\section{Perspektiver i problemformuleringen}

Det er godt at være opmærksom på, at man kan anlægge flere perspektiver i sin analyse.

- Fokus kan være vejlederen og vejlederens rolle/redskaber: Hvordan kan man som klinisk vejleder støtte en sygeplejerskestuderende til at vælge en anden uddannelse?

- Fokus kan ligeledes være den mulige effekt, vejledning kan have på den vejledte: Hvorledes jeg kan støtte de kliniske vejledere til at udvikle deres kompetencer, så de føler sig trygge i vejledningsfunktionen?

- Fokus kan være interaktionen mellem vejlederen og den vejledte. Hvilke udfordringer ligger der $\mathrm{i}$ at styrke samspillet mellem vejlederen og den vejledte i $X$ kontekst? Hvordan kan samspillet styrkes i X situation?

- Fokus kan være mere overordnet på vejledningens rolle i en given kontekst: Eks: Hvordan kan vejledning være en motivationsfaktor for at udvikle den studerendes personlige kompetencer? Hvilken betydning har supervision og coaching i relation til udvikling af de kliniske vejlederes kompetencer? Hvad er forskelle/ligheder - muligheder og begrænsninger?

Underspørgsmål kan være en god idé, da de kan guide og måske fungere som overskrift for nogle afsnit i opgaven.

\section{Formål}

Formålet er = er det formål, der er med at besvare problemformuleringen. Hvilken viden vil din besvarelse give dig? Og hvad kan du bruge den viden til?

- Måske er der et udviklingsprojekt på din arbejdsplads pt., hvor den indsigt, du får gennem opgaven, konkret kan bruges til at kvalificere dette projekt. I besvarelsen af formålet kan du skrive lidt om, hvordan den viden, du får, kan kvalificere projektet.

- Måske er der nogle helt praktiske udfordringer i dit job som vejleder, som du gerne vil blive klogere på. Hvordan forestiller du dig mere præcist, at den viden, du får gennem at skrive opgaven, kan hjælpe dig i din praksis? 


\section{Metodeafsnit}

Efter det indledende afsnit kommer metodeafsnittet. Her redegør du for, hvordan du vil undersøge dit problem. Du kan kort skitsere de teoretikere og undersøgelser, du har valgt.

- Hvorfor har du anvendt disse kilder?

- Hvordan kan de supplere hinanden og belyse din erkendelsesinteresse?

\section{Teoriafsnit}

I teoriafsnittet belyser du din problemformulering gennem de valgte teorier så præcist og nøgternt, som du kan. Dvs. minus personlig holdning - den gemmes til diskussionen! Du kan med fordel inddrage to teorier og lave en komparativ (sammenlignende) analyse og også gerne nogle undersøgelser, der måske er lavet indenfor området.

Det betyder, at dit fokus i teorigennemgangen er besvarelsen af følgende spørgsmål: Hvordan vil du besvare de spørgsmål, du stiller i din problemformulering set i lyset af teori \# 1 og \#2. Hvad siger f.eks. Egan, eller coaching eller en andre teori omkring fx: Hvordan kan vejledning motivere de studerende til at udvikle deres personlige kompetencer?

\section{Analyse}

\section{$B A V$-modellen}

I analysen kan BAV-modellen (Beskrivelse/analyse/vurdering) være en frugtbar måde at strukturere analysen på.

\section{Beskrivelse}

Hvad siges der i et citat? Eller det kan være et uddrag fra din empiri, som du analyserer. Det kan fx være et dokument, et billede eller noget andet fra den kontekst, som du undersøger. Genfortæl så konkret og objektivt som det er muligt, hvad citatet udtrykker uden at skrive/forhold dig til, hvad evt. hensigter der kan være med det sagte. Dette kan synes selvfølgeligt, men er det ikke, da der kan være mange måder at forstå og gengive et citat på. Beskrivelsen er dit udgangspunkt for analysen.

\section{Analyse/Tolkning}

I analysen bruger du dit teoretiske blik til at forstå din beskrivelse af citatet. Med andre ord: Hvordan kan man forstå det sagte i et teoretisk perspektiv? 


\section{Vurdering}

I vurderingen sammenholder $d u$ din teoretiske analyse med din problemformulering: Med andre ord: Hvordan forholder analysen sig til det, som du spørger om i min problemformulering?

Eksempel på en BAV analyse og sammenhcengen med problemformuleringen:

Problemformulering

Hvordan oplever stressramte medarbejdere deres arbejdssituation lige inden de sygemelder sig?

\section{Formål med opgaven}

At blive klogere på, hvordan en leder kan vejlede og støtte smedarbejderne så en sygemelding kan forebygges.

Citat: Informant Lotte siger: "Jeg syntes det var svart at henvende mig til nogen for at få hjelp, når jeg ikke nåede det, som jeg følte jeg burde kunne nå". Så jeg holdt mig mest for mig selv".

Beskrivelse:

- I citatet siger Lotte at, at hun synes, at det er svært at bede om hjælp, da hun 'burde' nå mere. Så derfor holder hun sig 'mest' for sig selv

Analyse

- Udsagnet illustrerer, hvordan Lottes stress er forbundet med en stigende isolation og tilsyneladende. Teoretisk beskrives ensomhed som et centralt karakteristika ved stress (reference). En nylig undersøgelse viser også, hvordan stress ramte osv. osv.

Vurdering

- Ift. problemformuleringen viser analysen af Lottes udsagn, at hun har følt sig så presset i sin arbejdssituation, at hun har isoleret sig. 


\section{Diskussion}

I diskussionsafsnittet sætter man de forskellige teorier op mod hinanden - igen i forhold til problemformuleringen/underspørgsmål:

- Hvad er ligheder/forskelle mellem teori 1 og 2?

- Hvad er muligheder og begrænsninger ved respektive teori 1 og 2 - set i lyset af din problemformulering?

- Hvad kan udbygges? Hvad mangler? Har du ideer til det?

- Her er det tilladt at inkorporere en mere personlig - begrundet og dermed kvalificeret (naturligvis $:$ ) - stillingtagen til dit problem.

\section{Konklusion}

Her redegør du for, hvordan din problemformulering kan besvares. Ofte gives der jo ikke entydige svar. Dvs., at du kigger på din problemformulering igen og besvarer den. En god konklusion er kort og præcis. Når opgaven skal læses af vejleder og eksaminator, starter vedkommende ofte med at læse indledning/problemformulering og så diskussion og konklusion. Det skal passe sammen som fod i hose!

\section{Perspektivering}

I nogle opgaver findes også en perspektivering efter konklusionen, hvor man kan diskutere de perspektiver, som rejser sig i forlængelse af besvarelsen af opgaven: Teoretisk, vejledningsmæssigt, etisk osv. Denne del af ikke obligatorisk og kan derfor sættes ind, hvis man føler behov for det.

\section{Referencer/litteraturliste}

Vær omhyggelig med både at referere i teksten og at lave litteraturlisten (fx efter APAstandarden) - det lægger vi vægt på! I selve brødteksten refererer du til litteratur på følgende måde: Jakobsen (2008: 33) - hvis det er side 33, du henviser til. Hvis det er en reference, der enten kun henvises til en gang eller ikke har stor betydning for opgaven, sættes den i en fodnote og ikke i litteraturlisten.

Litteraturlisten er en referenceliste. Dvs. at der skal stå de kilder, der eksplicit er refereret til i teksten. Kilderne opføres i alfabetisk rækkefølge forsynet med:

- Samtlige forfatter navne og årstal

- Tekstens titel 
- Evt. redaktør(e) og titel på den bog, teksten er en del af

- Udgiver (forlag, tidsskrift, institution eller myndighed)

- Publiceringsstedet og publiceringsnummeret/ evt. årgang

- Sidetal

Referencestandarder er forskellige. Nedenfor er gengivet AUs standarter(se mere her: http://library.au.dk/betjeningssteder/campus-emdrup-

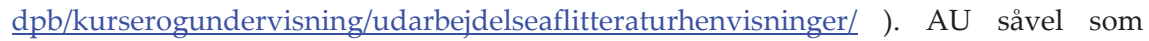
Aarhus University Library anvender American Psychological Association (APA) standard til angivelse af referencer. Referencerne nedenfor er eksempler på de mest almindelige bibliografiske referencer i henhold til APA-standarden:

\section{Bøger:}

Brock Jacobsen, P. \& Hobel, P. (1996). Religion og pædagogik. København: Undervisningsministeriet, Gymnasieafdelingen. (Gymnasieafdelingens skriftserie; nr. 18). Bruner, J. S. (1996). The culture of education. Cambridge, MA: Harvard University Press.

Jacobsen, B. (1991). Studier i dansk voksenundervisning og folkeoplysning: Socio-psykologiske analyser. København: Akademisk Forlag. Doktordisputats, Københavns Universitet.

\section{Antologier:}

Bøgh Andersen, P. (1986). Semiotics and informatics: Computers and media. I: P. Ingwersen, L. Kajberg \& A. Mark Pejtersen (Eds.), Information technology and information use: Towards a unified view of information and information technology (s. 34-47). London: Taylor Graham.

\section{Tidsskrifter.}

Butina, I., \& Stockmarr, M. (1999). Elektroniske produkter. DF-revy, 22(2), 43-44. Kniffel, L. (2001). The americanization of IFLA. American Libraries, 32(9), 34-38. 


\section{Dagsordner i vejledningen}

I den kollektive vejledning kan det vare godt at arbejde med dagsordner $i$ vejledningen, som gør det synligt for alle, hoad målet med og aktiviteterne i vejledningen er. I afslutningen af en vejledning kan dagsordenen for den næste vejledning evt. forhandles med de studerende. Nedenfor finder du eksempler på to forskellige prototyper for dagsordner fra Master i vejledning. Disse dagsordner er blevet et ritual på modul 3, da vi gennem de sidste 5 år har arbejdet med den struktur, som beskrives i dem.

\section{Eksempel på dagsorden for 1. Kollektive Akademiske Vejledning}

(Udleveres på skrift til de studerende i starten af vejledningen)

Intro til kollektive vejledningsforløb (3 gange) - herunder

- Responsuge: Vejledning pr. mail i uge X:

- Sende oplæg + spørgsmål senest XXX - respons fra onsdag til fredag i uge 50 skriftlig/mundtlig efter behag.

- Eksamen i løbet af de sidste 2 uger i januar.

- Husk at kigge i mapperne på BB, hvor der ligger

- tips til modul 3 opgaven på BB

- Papirer om indhold/forventninger til kollektiv akademisk vejledning

- Eksempler på tidligere modul 3 opgaver

\section{Prcesentations-runde - herunder:}

Alle studerende kommer med en overskrift på: Hvad er jeg blevet klogere på, når jeg går herfra?

(Vejleder skriver dette på white board)

\section{Selve vejledningen falder i 2 dele}

1 afdeling (30 min): Interview om problemformulering

Øvelsen er i 2 dele, hvor de to studerende gensidigt interviewer hinanden.

Første del

1. Interviewer den ene studerende den anden i 10 min (sæt fx mobilen til 8 min så der er tid til at afrunde samtalen). Vejleder kan evt. udlevere eks. på coachende 
spørgsmål og/eller systemiske spørgsmålstyper som inspiration til, hvilke spørgsmål den studerende kan stille. Formål med interviewet: At spørge ind til og lytte efter perspektiver på

a. Formål med opgaven og mulig/e problemformulering/er

b. Største udfordring/er lige nu

2. Efter interviewet er der en individuel skriftlig opsamling i 5 minutter, hvor

3. Både interviewer og den interviewede skriver hvad de har hørt som mulige svar på de 3 punkter, som har været omdrejningspunktet i interviewet. Interviewer skriver, hvad hun har hørt - og den interviewede skriver, hvor interviewet har bragt hende hen ift. formålet med opgaven.

4. Som afslutning på den første del af øvelsen giver interviewer den interviewede sine noter. Så ofte kan det ske, at interviewerens bud på en problemformulering rammer lige i plet.

I anden del bytter de to studerende roller - og øvelsen gentages.

\section{Pause i $10 \mathrm{~min}$.}

\section{2. afdeling (ca. 7 time)}

Efter interview øvelsen: Plenum med hvert par i ca. 35 minutter (før og efter en pause)

- Parret opsummerer, hvad de har hørt/skrevet i plenum

- Vejleder kommer med kommentarer

- De 2 andre medstuderende kommer evt. med kommentarer

\section{Afslutning:}

De studerende opsummerer skriftligt, hvad de hver især vil arbejde med til næste vejledning.

Evt. gennem en non-stop-skriveøvelse (se bilag

- Dette kan gøres i grupper/par eller enkeltvis.

- Opsummeringen kan evt. sendes til vejleder, så hun ved, hvad de studerende arbejder med kan organisere den næste vejledning ift. dette.

- Hvis der er spørgsmål, som ikke er blevet besvaret i vejledningen, som vejleder skal afklare, sender de studerende en samlet mail med disse spørgsmål gruppevis.

- Runde, hoor hver studerende siger - med afsxt $i$ det, hun har skrevet:

Hvad er mit næste skridt? Hvad vil jeg arbejde på til den næste vejledning? 
Dagsorden: 2 + 3. Kollektive Akademiske Vejledning med reflekterende team

\section{Dagsorden}

\section{(15 min) Intro-runde}

Hver studerende kommer med en overskrift på, hvad vil han/hun gerne have med fra vejledningen.

Herefter er der 20-25 min til hver opgave på følgende måde (vejleder styrer tiden)

- (5 min) Introducer din tekst/spørgsmål og hvad er evt. er sket siden du har sendt dem.

- Fortæl, hvad du har brug for gruppens hjælp til/respons på

o Problemformulering, teori eller metode? Eller noget andet?

- Hvad er det præcist du vil have os til at kigge på?

- (15 min): Reflekterende team: Resten af gruppen taler om spørgsmålene, mens den studerende lytter med ryggen til de andre og skriver (15 min)

- (5 min) Ordet gives tilbage til dig og vi spørger: Hvad har du særligt hæftet dig ved? Hvad vil du arbejde videre med?

20 min til fælles opsamling (dvs. der er ikke opsamling efter hver runde - opsamlingen er først til sidst)

- Hvad har jeg hæftet mig ved i de andres refleksioner?

- Hvad er mit næste skridt?

KAV 3 er som KAV 2 og desuden afsættes tid til intro om eksamen og vejledning inden aflevering 


\section{Rammer for eksamen}

- et eksempel fra Master i Vejledning

Klare rammer og aftaler omkring det, som forventes af de studerende til prøver og eksaminer giver mindre stressede studerende og bedre eksaminer. Derfor har vi lavet en vejledning til eksamen på Master uddannelsen $i$ Vejledning, som uddyber rammerne ift. studieordningen, den tid, der er afsat til eksamen og giver ideer til, hoordan den studerende kan bruge tiden bedst muligt.

I studieordningen står der vedrørende mundtlig eksamination i masterprojektet

Indleveret masterprojekt på maksimalt 60 normalsider efterfulgt af mundtlig eksamination af 45 minutters varighed (inklusiv votering). Den mundtlige eksamination tager udgangspunkt i masterprojektet og behandler en problemstilling, som den studerende har formuleret og som er godkendt af eksaminator.

Udarbejdes masterprojektrapporten af en gruppe øges sideantallet og varigheden af den mundtlige eksamen:

- 2 studerende: maksimalt 80 normalsider efterfulgt af mundtlig gruppeeksamen på 1 time og 15 minutter (inklusiv votering)

- 3 studerende: maksimalt 100 normalsider efterfulgt af mundtlig gruppeeksamen på 1 time og 45 minutter (inklusiv votering).

Bedømmelse sker på grundlag af en samlet vurdering af masterprojektet og den studerendes mundtlige præstation ved eksaminationen.

Eksamen skal altså - som det står ovenfor - vare i alt 45 minutter - inklusive votering.

Denne tid fordeles på følgende måde

- 10 min til et oplæg fra den studerende 
- 20-25 minutter til dialog - Og - her kan den studerende skrive stikord til relevante diskussioner, der kan rejse sig på baggrund af projektet - og måske fortsætte diskussionerne selv. Alternativt er det også vigtigt, at lade eksaminator og censor komme til og stille spørgsmål, så de får mulighed for at stille de uafklarede spørgsmål, der kan være.

- Knapt 5 minutter til afrunding. Her spørges den studerende: Er der ellers noget du gerne vil sige/understrege/samle op på?

- 5 til eksaminators og censors votering

- 5 til at den studerende får sin karakter og feed-back.

\section{Tips til eksamen i masterprojekt}

\section{En spise-seddel for eksamen}

Det er en god idé at give eksaminator og censor en spiseseddel med en dagsorden for de tematikker du gerne vil tale om. Her kan du evt. indikere de spørgsmål, som du gerne vil diskutere efter dit oplæg. Overvej i den forbindelse mulige svar på disse spørgsmål.

Lav evt. en mind-map over oplægget til eget brug.

Begynd med evt. korrektioner til selve opgaven - men kun hvis der er tale om større korrektioner/fejl

- Problemformulering/stilling

- Teori

- Metode

- Fund

\section{Perspektiver}

Herefter kan du invitere til en diskussion af mere overordnede perspektiver i forhold til dit projekt evt. med udgangspunkt i nedenstående tematikker

\section{Teori}

- Andre (vejlednings)teoretiske indfaldsvinkler end den du har brugt? Hvordan, hvorfor - og med hvilken effekt?

- Begreber

- Hvad kunne et fokus på andre begreber have afdækket i analysen? 


\section{Metoder}

- Kunne du have anvendt andre metoder? Hvorfor/hvordan og med hvilken effekt?

\section{Praksis}

- Egen praksis: Hvad bør/kan omtænkes/revideres - og hvordan?

- Videndeling: Hvordan vil du formidle din nye viden i din egen praksis?

- Vejledningspraksis betydning af dine fund på et mere overordnet/generelt plan for vejledningspraksis - samfundsmæssige/institutionelle perspektiver

\section{Etiske overvejelser?}




\section{Non-stop skriveøvelse}

Non-stop skriveøvelser kan være en kort og præcis måde at afslutte og evaluere eller begynde en vejledning på-skriftligt og mundtligt. Formålet med denne form for evaluering er at få indblik $i$ deltagernes umiddelbare tanker, oplevelser og læring $i$ forbindelse med vejledningen. Efter skriveøvelsen kan vejleder samle det, som de studerende har skrevet ind og bruge det fremadrettet $i$ sin tilrettelxggelse af vejledningen.

I en non-stop skriveøvelse skriver hver studerende i ca. 5 minutter eller til de har skrevet $1 \frac{2}{2}$ til 1 side, hvor han/hun har svarer på følgende spørgsmål:

- Hvad tager du med dig fra i dag, som har gjort et særligt indtryk?

Non-stop skrivning betyder således, at deltagerne ikke må løfte pennen fra papiret, så de begynder at censurere eller overveje det, de skriver.

Efter den studerende har skrevet i 4 minutter skal hun/han kigge teksten igennem og understrege 3 ord, som er centrale for hendes/hans oplevelse.

Endeligt udvælges 1 ord ud af de 3, som den studerende siger højt i plenum. 


\section{Organisering af peer-dialoger}




\section{Opponentfunktion i vejledningen}

Opponentfunktionen kan fremme de studerendes læring, da rollen som opponent indebærer, at man med undersøgende spørgsmål udfordrer og kvalificerer problemstillinger $i$ andres skriftlige eller mundtlige oplag. Med andre ord kan både den, som opponerer og den som bliver opponeret på, lære noget nyt. Opponance kan være velegnet både til planlagte studieaktiviteter og som forberedelse prøver.

\section{Vejledning til opponentfunktionen (til de studerende)}

Når du/I opponerer på andres oplæg, søger du/I sammen med modtageren efter nye perspektiver og synsvinkler. Det vil sige at både opponent og modtager bør være velfunderet i den litteratur, der danner afsæt for problemstillingen i oplægget. Selvom "at opponere" betyder at modsætte sig eller komme med indvendinger, skal de spørgsmål, som I ønsker at stille den gruppe, som I opponerer på, ikke formuleres som et angreb, der tvinger modtageren i en forsvarsposition. Tværtimod er det vigtigt at være anerkendende i jeres respons. Det betyder, at I prøver at vise, at I har forsøgt at forstå, hvilke hensigter oplægsholderne har med deres argumentationer. Det kan I gøre ved at følge disse anbefalinger (Rienecker and Jørgensen, 2011):

$\mathrm{Du} / \mathrm{I}$ læser og analyserer det skriftlige oplæg grundigt.

- $\mathrm{Du} / \mathrm{I}$ læser eller genlæser evt. litteraturen som danner grundlag for problemstillingerne i oplægget.

- Når Du/I formulerer spørgsmål, tager I afsæt i korte referater af den del af oplægget, I ønsker udfoldet.

- Hvad er godt?

- Hvad vil du/I selv gerne forstå bedre?

- Hvad undrer du/jer? Hvad forstår I ikke?

- Giv den fremlæggende gruppe mulighed for at uddybe, forklare og argumentere.

- Søg ikke efter bestemte svar.

- Sæt parentes om din/jeres egen forforståelse og vær i stedet nysgerrige på oplæggets teori, indhold og metoder.

- Undgå at have fokus på detaljer og petitesser. Alt i alt søger I efter områder, som kan fremme både opponenter og oplægsholderes læring. Eksempler på spørgsmål der giver mulighed for uddybning, forklaring og argumentation

- Hvordan mener I, at.... ? 
- Hvilke tanker/overvejelser har I gjort i forhold til....?

- I skriver..... kunne I uddybe det? Fortæl hvordan ...... ?

- Efter have givet et kort referat af en del af oplægget kan I evt. spørge: Når vi læser/hører .... oplever vi .....kan I udfolde det?

\section{Referencer}

RIENECKER , L. \& JØRGENSEN, P. S. 2011. Få og giv feedback. In: RIENECKER , L.\& JØRGENSEN, P. S. (eds.) Studiehåndbogen - for studiestartere på videregående uddannelser. København: Samfundslitteratur. 


\section{Par-øvelser i vejledningen}

Parøvelser kan vare gode at tage $i$ brug $i$ alle faser af skrive- og vejledningsprocessen. Nedenfor giver vi to eksempler på, hvordan man kan bruge par-øvelser i problemformuleringsfasen og kommer med forslag til, hvordan man kan bygge videre på denne form gennem at lade flere par møde hinanden og reflektere sammen ift. et givent tema.

\section{2 par-øvelser i problemformuleringer}

\section{$\varnothing$ velse med 1 par}

\section{Interview om problemformulering}

Denne par-øvelse kan være god at introducere i start fasen af et skriveforløb. Øvelsen falder i 2 afdelinger, hvor de to studerende gensidigt interviewer hinanden.

I første afdeling

1. Interviewer den ene studerende den anden i $10 \mathrm{~min}$ (sæt fx mobilen til $8 \mathrm{~min}$ så der er tid til at afrunde samtalen). Vejleder kan evt. udlevere eks. på coachende spørgsmål og/eller systemiske spørgsmålstyper som inspiration til, hvilke spørgsmål den studerende kan stille. Formål med interviewet: At spørge ind til og lytte efter perspektiver på

- Formål med opgaven

- Mulige problemformulering/er

- Største udfordring/er lige nu

2. Efter interviewet er der en individuel skriftlig opsamling i 5 minutter, hvor både interviewer og den interviewede skriver hvad de har hørt som mulige svar på de 3 punkter, som har været omdrejningspunktet i interviewet. Interviewer skriver, hvad hun har hørt - og den interviewede skriver, hvor interviewet har bragt hende hen ift. formålet med opgaven.

3. Som afslutning på den første del af øvelsen giver interviewer den interviewede sine noter. Så ofte kan det ske, at interviewerens bud på en problemformulering rammer lige i plet.

I anden afdeling bytter de to studerende roller - og øvelsen gentages. 


\section{Kvalificering af problemformuleringer}

Denne øvelse kan bruges, når de studerende har formuleret nogle bud på mulige problemformuleringer.

Evt. efter at vejleder har holdt et kort oplæg om problemformuleringer - eller de studerende har gennemgået Scribo på Studie-metroen:

\section{http://studiemetro.au.dk/atskrive/scribo/}

Til vejledningen medbringer hver studerende

- En kort beskrivelse af motivationen for emnet. Maks. 1 side

- Mindst to og gerne 3 bud på en problemformulering

Hver studerende vælger en medstuderende, som de gerne vil have respons fra på deres problemformulering.

De to studerende bytter problemformuleringer i 10-15 min, hvorefter de giver hinanden feedback på dem ift. principperne for feedback - de $3 \mathrm{~K}^{\prime}$ er: Konkret, konstruktiv og kritisk (se også "Stilladsering af akademisk skrivning" i inspirationskataloget)

\section{2 par mødes}

Ovenstående øvelser kan udvides så to par mødes og udveksler deres pointer i 30 min.

Det gælder for alle par-øvelser, at det kan være særdeles frugtbart at bygge denne dimension på øvelsen.

Til plenum kan de studerende medbringe:

- 3 centrale erkendelser, som de har oplevet, at par og 'dobbelt-par-øvelsen' givet dem

- 2 - maks. 3 spørgsmål til plenum

Øvelsen med at forhandle og udvælge de centrale spørgsmål til plenum kvalificerer den fælles dialog.

Og - ofte sker det at det er de samme spørgsmål, som stilles - og det giver vejlederen mere tid til at besvare dem. 


\section{Triade-øvelser i vejledningen}

Princippet $i$ triade-øvelser er, at der er to som taler sammen, mens den 3die person agerer observatør på deres samtale. Dette format rummer en uendelig række muligheder og kan anvendes på alle tidspunkter $i$ skriveprocessen ligesom formatet kan anvendes både af de studerende og vejledere, som sparrer med hinanden og evt. har observeret hinandens vejledning eller til at give respons på udvalgte afsnit af en opgave. Nedenfor giver vi en kort introduktion til grundformatet $i$ en triade-øvelse, som vejlederen så kan tilpasse ift. det tema, som skal sættes $i$ spil i øvelsen.

\section{Grundformat i en triade-øvelse}

I øvelsen er rollerne fordelte.

- En interviewer/giver feedback og en bliver interviewet/får feedback.

- Den tredje person i gruppen er observatør og styrer tiden.

Der er 20 minutter til hver person i gruppen - dvs. at øvelsen varer $i$ alt 60 minutter.

Alle i gruppen skal i løbet af seancen prøve at være henholdsvis den vejledte, vejleder og observatør. Vælg desuden en person fra gruppen, som kan sammenfatte hovedpunkterne i alle 3 før-vejledninger i plenum efter øvelsen er slut. Der er stikord til sammenfatning nederst på side 2 .

\section{Øvelsen forløber på denne måde}

- Først fordeler I bogstaverne A, B og C mellem jer.

- Dernæst taler A med B i 10 minutter mens C lytter på og passer tiden. Når der er 1-2 minutter tilbage siger $C$ til.

- Efter øvelsen refererer C, hvad han/hun har hørt og kommer evt. med nogle refleksioner i forhold til det.

- Følg skemaet nedenfor i resten af øvelsen.

\begin{tabular}{|l|l|l|}
\hline A: Interviewer & B: Interviewes & C: Observatør \\
A: Observatør & B: Interviewer & C: Interviewede \\
A: Interviewede & B: Observatør & C: Interviewer \\
\hline
\end{tabular}




\section{Eksempel på en triade-øvelse}

Nedenfor eksemplificeres det, hvordan man kan arbejde i en triade. Eksemplet kommer fra en triade, som vi har arbejdet med i en øvelse om kollegial vejledning.

\section{Inspiration til interview (10 $\mathrm{min})$}

(hvor den kollegiale vejleder interviewer sin kollega inden hun skal observere hende i praksis)

I interviewet afklares, hvilke områder den interviewede ønsker at fokusere på (se nedenfor). Prøv at være nysgerrig som interviewer og sammenfat med jævne mellemrum det, du har hørt. I den sidste del af interviewet kan du evt. komme med kommentarer/forslag til det, din med-studerende fortæller. Nedenstående er forslag til spørgsmål og til forløbet i samtalen.

Om grundlaget for den kollegiale supervision/vejledning eller den studerendes opgave

Tag udgangspunkt i den vejledtes behov/ønsker og spørg f.eks.:

- Hvad ønsker du at opnå med X? Hvad vil du gøre og hvorfor?

- Hvilken viden/erfaringer trækker du på i situationen?

- Hvilke værdimæssige prioriteringer ligger til grund? Hvorfor vil du gøre det sådan?

- Hvad tænker du ville være relevant for mig at give feedback på?

\section{Interviewerens forståe/se og evt. bidrag}

Vejleder opsummerer, hvad han/hun har hørt kollegaen sige, for at understrege, at det er den interviewedes udsagn, som er i fokus. Dernæst kan intervieweren komme med egne tanker og ideer, og parterne kan sammen diskutere alternative muligheder overvejelser.

\section{Inspiration til observatørrollen}

(her er fokus på samtalen - men det kunne også vaere på teoretiske eller metodiske tematikker...eller noget andet, som er relevant for vejledningens tema)

$\mathrm{C}$ observerer uden at blande sig i samtalen. $\mathrm{C}$ kan $\mathrm{fx}$ observere og lade sig inspirere af følgende spørgsmål: 
- Hvilke spørgsmål kommer A med og hvordan reagerer A på B's spørgsmål/kommentarer?

- Hvordan er kropssproget hos A og B?

- Hvilke spørgsmål, synes du, fungerede godt i samtalen og hvorfor?

- Hvad opfattede du den interviewede/vejledte lagde særligt vægt på i sine svar?

\section{0 min: Efter interviewet}

Efter interviewet får $\mathrm{A}, \mathrm{B}$ og $\mathrm{C}$ lejlighed til at kommentere på det $\mathrm{i} 5$ minutter (kan evt. forlænges).

- Først fortæller observatøren C om det, som hun har observeret uden at blive afbrudt.

- Derefter får A og B lejlighed til at kommentere på C's observationer og fortælle hvordan det var henholdsvis at vejlede/interviewe og blive interviewet

Den vejledte kan fx fortælle lidt om:

- Hvordan opleves det at blive interviewet? Hvad overrasker mig mest?

- Hvad gjorde intervieweren, som var godt? Hvad vil jeg se mere/mindre af?

10 min: Som afslutning på øvelsen, forhandler de studerende centrale til pointer til plenum. 


\section{At arbejde med et reflekterende team i vejledningen}

Arbejdet med reflekterende team kommer fra supervisionspraksis (Andersen, 1996). Det er en meget effektfuld pædagogisk metode, da den bygger på et enkelt princip om at de, som er tilhørere til en dialog, ofte er meget klogere på, hvad man kunne sige eller mene om en den problem stilling, der tales om, end den person, som fremforer en problemstilling. Oplagget til teamets arbejde er derfor en dialog mellem to eller flere studerende - evt. hvor en vejleder interviewer dem om de udfordringer, som de oplever $i$ skriveprocessen. Målet med dialogen er således at formulere de mest presserende spørgsmål til det reflekterende tema, som de studerende har brug for en afklaring på. Inden dialogen kan vejlederen og/eller de studerende arbejde med at udvikle og formulere bestemte kategorier eller spørgsmål, som teamet skal forholde sig til. Det kan fx være: Hvilke problematikker hører jeg $x$ tale om? Hvilke taler han ikke om? Hvordan adskiller de problematikker, jeg horer, sig fra de udfordringer, som jeg selv oplever? Herefter præsenterer teamet deres tanker om problemstillingen på en respektfuld og anerkende måde. Mens de taler, må den/de som 'ejer' den, sidde med siden eller ryggen til og lytte uden at blande sig $i$ de kommentarer, som teamet kommer med. I starten kan det måske virke noget kunstigt, men efterhånden naturligt og nødvendigt. Hvis teamet og den studerende, som har uafklarede spørgsmål, sidder overfor hinanden sker der nemlig det, at den studerende naturligt vil begynde at besvare eller kommentere det, som teamet taler om. Nedenfor findes en mere udfoldet beskrivelse af, hvordan man kan arbejde med reflekterende team $i$ vejledningen, som evt. kan udleveres til de studerende.

Formålet med et reflekterende team er at få nuanceret og udvidet dialogerne om et givent tema.

Et grundlæggende princip i brugen af reflekterende team er at der skiftes mellem at deltagerne i en gruppe indtager lytte og tale positioner med afsæt i nogle på forhånd formulerede kategorier.

Med andre ord skiftes der mellem at forskellige personer/grupper i den store gruppe taler og lytter til hinanden. Det er kun fantasien, som sætter grænser for, hvor og hvordan den teknik kan anvendes i vejledningen. Nedenfor kommer vi med nogle eksempler på, hvordan det kan gøres. 


\section{Eksemplarisk vejledning med reflekterende team}

1. Vejlederen udvælger/spørger 1, 2 eller 3 studerende, som beskriver de samme udfordringer i deres skriftlige oplæg inden vejledningen.

2. Resten af gruppen inddeles i undergrupper. Afhængigt af, hvor stor gruppen erkan gruppen inddeles i op til 5-6 undergrupper - eller bare 2 - afhængigt af, hvor lang tid vejlederen afsætte til øvelsen.

3. Hver undergruppe får nu en kategori, som de skal forholde sig til/lytte efter mens vejlederen interviewer de studerende, som er udvalgt/spurgt om de vil interviewes. Disse kategorier kan fx være:

\section{Problematik}

- Hvad hører jeg, at den studerende gerne vil arbejde med? Hvilken problematik og hvad er formålet med projektet?

- Hvordan forholder jeg mig til denne problematik?

\section{Sammenligning}

- Hvordan ligner de problematikker, som de studerende beskriver mit projekt?

- Hvordan er de forskellige og hvorfor?

\section{Dilemma}

- Hvad hører jeg er det største dilemma for de studerende?

- Er der forskel på, hvad det er? (gælder hvis der er flere studerende, som interviewes)

- Hvordan kunne disse evt. hånderes?

\section{Teori/metode}

- Hvad er lighed/forskel på det teoretiske perspektiv, som de studerende arbejder arbejder med i forhold til mit eget perspektiv?

- Hvad er styrken ved dette perspektiv? Hvad er svagheden ift. problemstillingen? Osv. osv.

4. Vejlederen interviewer nu de/n studerende i 15-30 min. og bruger whiteboard til at notere nøgleord/spørgsmål/kommentarer på. I interviewet søger hun at få de studerende til at præcisere, hvad det er, som de har brug for input til fra de medstuderende og vejlederen. 
5. Grupperne i det reflekterende team får herefter 15-30 min til overveje og sammenfatte deres kommentarer ift. deres kategori. Imens skriver de studerende, som er blevet interviewet deres oplevelse af interviewet ned - indholdsmæssigt/formmæssigt.

6. Vejlederen hører grupperne i det reflekterende team, mens de studerende, som er blevet interviewet, lytter på - med ryggen til (ellers bliver de bare involveret $i$ den dialog, som foregår mellem vejlederen og de andre studerende). På denne måde får de ro til at lytte efter og notere de udsagn ned, som de særligt kan koble sig til.

7. Efter teamet er hørt, vender vejlederen tilbage til de studerende, som blev interviewet i forhold til deres projekt før det reflekterende team kom på. Hun spørger dem nu: Hvor har teamets kommentarer bragt jer hen? Formålet med det sidste interview er at de studerende bliver afklaret ift. næste skridt i skriveprocessen. Det sidste interview er kortere end det første og varer maks. 20 min.

8. Som afslutning spørger vejlederen den store gruppe: Hvad har gjort særligt indtryk? Her kan non-stop skrive-øvelsen (se inspirationskataloget) evt. bringes i spil.

\section{Andre måder at arbejde med reflekterende team på}

Ovenstående er en måde at arbejde med reflekterende team på. En anden kan være at inddele en større gruppe i 2/3 grupper. Vejlederen kan så først tale med en af grupperne mens den anden/de to andre grupper lytter på. Herefter hører den anden gruppes refleksioner på det, som hun talte med den første gruppe om - og sådan kan det fortsætte. Når de studerende er socialiseret ind i denne måde at skabe dialoger på i det kollektive rum kan de selv styre processen og vejlederne kan vælge, hvilken position hun gerne vil indtage - måske som en ekspert, der bliver inviteret ind i dialogen, når der er behov for det $:$; 


\section{Det engelske parlament}

Øvelsen "det engelske parlament" har fået navn efter det engelske parlament, som jo er karakteriseret ved at regeringen og oppositionen sidder overfor hinanden og skiftevis fremfører deres argumenter for og imod en given sag. I denne øvelse deles gruppen derfor $i$ to, og hver gruppe arbejder med at udvikle og fremføre lige netop deres argumenter for en given sag. Ydermere kan det vare at det, som de studerende skal argumentere for ikke er det perspektiv eller synspunkt, som de selv abonnerer på. Formålet med øvelsen er derfor, at de studerende skærper deres argumentation og gennem ikke kun at arbejde med sit eget men også andre perspektiver på en sag - det kan fx være teoretiske, metodiske eller etiske forhold, som diskuteres i øvelsen.

\section{$\varnothing$ velsen starter med at gruppen deles i 2}

30 min eller mere:

Hver gruppe arbejder med at udvikle argumenter for et givent teoretisk og metodisk perspektiv - og modargumenter mod det perspektiv, som den anden gruppe arbejder med. En del af øvelse kan være, at den studerende måske kommer til at arbejde med og abonnere på et perspektiv, som er forskelligt fra det perspektiv, som hun selv arbejder med i sit projekt.

\section{$\varnothing$ velsen}

I selve øvelsen sidder de to grupper overfor hinanden, som politikerne gør det i det engelske parlament.

Herefter starter en af grupperne med at fremføre argumenter for, hvorfor man fx skal vælge en kvalitativ metode eller et givent teoretisk perspektiv frem det, som den anden gruppe mener, er det rigtige.

Herefter er ordet frit i den forstand, at hver gang en deltager ønsker at tale, må han eller hun rejse sig op og fremføre sit argument.

\section{Opsamling}

De studerende laver en non-stop skrive øvelse over spørgsmålet: Hvad har øvelsen gjort mig klogere på? 


\section{"Work-in-progress-seminar"}

I dette bilag uddybes det, hvordan vejleder kan arbejde med peer-feedback i form af WIP seminarer-en form, som er velintegreret ift. et ph.d.-forløb, men som også kan tages i brug på kandidat og master-studier. Bilaget kommer fra et WIP-forløb på Masteruddannelsen i Vejledning og kan bruges som skabelon i tilrettelæggelsen af WIP på andre uddannelser.

Kære studerende

"Work - in - progress" (WIP) seminar foregår på DPU i København fra 10 - 16

På et WIP seminar får I lejlighed til at

- Præsentere jeres projekt: Hvad vil I, hvorfor og hvordan?

- Få respons på projektet og de aktuelle problemer/behov I har fra andre medstuderende og underviserne på seminaret..

Formålet med seminaret er således, at I får forskellige input til jeres skriveproces og (forhåbentlig (:)) bliver klar på, hvad I skal arbejde videre med og hvordan.

Responsen foregår i grupper med 6, som alle får hinandens oplæg inden WIP. I gruppen er man opponent for en anden studerende - ligesom man selv får feedback fra en anden studerende. Noget for noget (:) De som ikke opponerer, får således heller ikke feedback.

WIP foregår om formiddagen. De spørgsmål, som har rejst sig i gruppernes samtaler om eftermiddagen, tages med i plenum efter frokost. På seminaret får alle respons fra en medstuderende og de vejledere, som deltager i seminaret. Det betyder, at hver studerende skal opponere på ét masterprojekt.

Responsen på WIP er fin forberedelse på spørgsmål, der evt. kan komme til eksamen. De studerende, som ikke har sendt noget er velkomne til at komme og lytte på. Til frokost regner med at vi spiser fælles frokost i Grafisk Kantine (desværre for egen regning $:)$.

\section{Strukturen under WIP for hver studerende er som følger:}

Hvert projekt får ca. 25 min, som er fordelt på følgende måde. 
1. Den studerende får $5 \mathrm{~min}$. til en kort præsentation af hans/hendes aktuelle spørgsmål/behov. Hvorfor stiller jeg netop disse spørgsmål i det rundsendte materiale? (max 5 minutter).

2. Den medstuderende, der opponerer, har nu 10 minutter mens den studerende lytter. Husk den meget simple grundregel for konstruktiv kritik er: ros-ris-ros.

3. Som opponent må du gerne forholde dig til klarheden i formidlingen. Hvad er det der undersøges? Hvilke metoder anvendes? Hvilke diskussioner kan rejses på baggrund af projektet? Hvordan ser du sammenhængen mellem disse? Er der passager, hvor du som læser savner viden?

Formuler 3 centrale spørgsmål til projektet, som din medstuderende kan forholde sig til.

4. Til slut er der 10 minutter til en afsluttende diskussion af de perspektiver, der er rejst indtil nu. Her kan medstuderende få lejlighed til at komme med kommentarer/spørgsmål.

5. Afslutningsvis formulerer den studerende, hvad hans/hendes næste skridt i skriveprocessen er. Hvor har WIP seminaret bragt dig hen i din skriveproces?

Opsamlende er grundreglerne under WIP:

- Opponenterne må ikke afbrydes under deres opponering.

- Den studerende, som modtager respons kan sidde og lytte, skrive ned - og efter responsen får han/hun lejlighed til at stille uddybende spørgsmål/kommentere på det, som er blevet sagt.

- Det er en god idé at undgå lange forklaringer og i stedet spørge ind til, hvordan det er muligt at arbejde videre med de uklarheder, som opponeringen har rejst.

\section{Send materiale til WIP}

- til hmn@dpu.dk. Herefter udarbejdes opponentliste som du får tilsendt. Dvs. at du skal regne med at have tid til at forberede dig til seminaret.

- Og skulle du ikke blive klar med dit materiale kan du sagtens deltager i lytte (og hygge) position. Send en mail, hvor du gør opmærksom på det.

\section{Send ikke docx-filer ikke alle kan åbne dem (:)}

Til WIP må I sende maks 8 sider (eksklusiv litteraturliste):

- Indholdsfortegnelse

- Problemformulering 
- Motivering for problem: Formål med projeket

- Undersøgelsesdesign: Hvilken empiri arbejder I med, hvorfor og hvordan?

- Valg af teori (kort)

- Litteraturliste

- Mindst to begrundede spørgsmål til opponenterne: Spørgsmålene skal stå som det første i dokumentet. Hvad er mine spørgsmål? Hvorfor stiller jeg netop disse spørgsmål (relevans)?

Husk at skrive navn og sidetal i sidehovedet på alle sider i dit dokument.

- Måske har I allerede sendt en del af ovenstående til jeres vejleder.

- Så sender I bare det samme igen til jeres opponenter - eller - endnu bedre - så langt, som I er nået nu.

- Husk at jeres projekt bliver læst af anden studerende nu, som ikke kender til jeres projekt. 


\section{Cafemodellen}

Cafemodellen: Anerkendende feedback i projektgrupper. Oprindeligt trykt i Dansk Universitetsprdagogisk Tidsskrift nr. 6, 2008 


\title{
Cafemodellen: \\ Anerkendende feedback \\ i projektgrupper
}

\author{
Lene Tortzen Bager, lektor, Center for Undervisningsudvikling, Aarhus Universitet
}

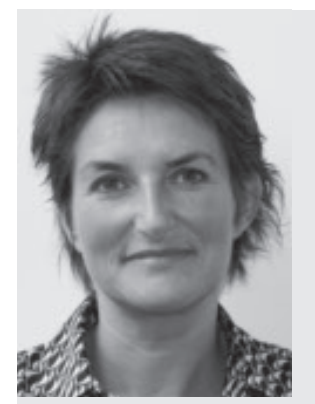

Lene Tortzen Bager er tidligere lektor ved Institut for ÆEstetiske Fag, AU, hvorfra hun har undervisningserfaring fra æstetik- og kultur-faglige forløb og forskningsbaggrund inden for samtidskunstens teori, historie og reception. Siden 2008 er hun ansat som lektor ved Center for Undervisningsudvikling, hvor hendes forsknings- og udviklingsopgaver vedrører universitetspædagogik, involverende undervisningsformer, entrepreneuriel didaktik, kollegial supervision, vejledning og feedback.

Kan feedback på meningsfuld måde varetages af de studerende selv? Kan de studerende loere at anvende feedbackformer, der kvalificerer dem til at indga i fagligt larende fallesskaber? I artiklen beskrives erfaringer med at lade studerende give hinanden feedback gennem cafemodellen $i$ forbindelse med projektarbejde. Den paedagogiske hensigt hermed er, at de studerende fär erfaring med en anerkendende tilgang, med at anvende dialogens lytte- og tale-positioner aktivt samt med at konstituere sin rolle som studerende i et laerende fallesskab.

\section{Introduktion}

Cafemodellen er en feedbackform, jeg har eksperimenteret med i forbindelse med udvikling af et nystartet undervisningsforløb på kandidatuddannelsen i Oplevelsesøkonomi ved Nordisk Institut, Aarhus Universitet i 2007. I denne artikel beskriver jeg principperne bag cafemodellen, ligesom jeg gennemgår selve metoden i modellen og erfaringerne med at anvende modellen.

\section{Hvad er principperne bag cafémodellen?}

I cafemodellen anvendes en samtalemodel, som bl.a. kendes fra coaching, kollegial supervision og fra reflekterende teams. ${ }^{1}$ Modellen kan bruges $\mathrm{i}$ forbindelse med gruppearbejde og er særligt velegnet, når der er tale om længerevarende projektarbejde, hvor samtalerne kan hjælpe med at afdække og fastholde faser i processen.

Modellen beskriver tre roller eller funktioner i en systemisk samtale, hvor hver projektgruppe på skift varetager en funktion i samtalen:

- Fokusgruppen har viden og ressourcer

- Supervisionsgruppen hjælper med at uddybe og konkretisere fokusgruppens emne gennem en anerkendende tilgang

- Iagttagergruppen lytter aktivt, tager notater, samler op og beskriver samtalens forløb

Den systemiske teori, som denne samtaleform bygger på, betoner, at den enkeltes handlinger og holdninger sker $\mathrm{i}$ et fællesskab, som er en betydningsgivende kontekst.Ændres et led i fællesskabet, ændres hele fællesskabet; og teorien vægter denne mulighed for forandring. Samtalen er desuden baseret på en anerkendende tilgang, Appreaciative Inquiry, som tager afsæt i, at den enkelte har ressourcer, viden og færdigheder, som kan komme til udtryk gennem en anerkendende og undersøgende samtale. I forhold til cafemodellens roller betyder det, at fokusgruppen har viden og ressourcer, som supervisionsgruppen kan hjælpe med at uddybe og konkretisere gennem anerkendende og åbent undersøgende spørgsmål i en samtale, som iagttagergruppen lytter til, samler op på og skaber perspektiv i. Tankesættet bag den anerkendende tilgang tager således udgangspunkt $i$, at den anden gennem refleksion og undersøgelse af erfaringer kan blive klogere på betydninger, viden og muligheder. At tilgangen i samtalen er anerkendende betyder ikke et fravær af en traditionel kritisk (akademisk) diskurs, men en kritisk diskurs, der formuleres gennem anerkendelse og undersøgelse. Kritiske synspunkter kan formuleres positivt som undersøgende og afdækkende spørgsmål, som f.eks. «Hvad ville det gøre ved Jeres idé, hvis I...?" 
Denne case er et eksempel på den opgave, som grupperne fik efter en introduktion til cafemodellen. Casen startede gruppernes arbejde med cafemodellen.

\section{Case: Konstruer en kollektiv identitet for gruppen}

Baggrund: De studerende har ved studiestart oploadet individuelle portrætter af sig selv med beskrivelse af faglig baggrund, interesser og begrundelse for deres valg af kandidatuddannelsen i Oplevelsesøkonomi. Herefter er de studerende af lærergruppen blevet inddelt i projektgrupper, og denne første cafe har til formål at understøtte gruppens proces med at etablere en gruppeidentitet.

Holdet er på dette tidspunkt blevet introduceret til cafemodellen og har prøvet den i ultrakorte samtale-runder.

Instruktion til øvelsen:

I skal konstruere en kollektiv identitet for Jeres gruppe: hvorfor er I en gruppe? Hvad er Jeres gruppes omdrejningspunkt? Hvorfor er dette Jeres omdrejningspunkt? Jeres diskussioner og undersøgelser skal udmøntes $i$ et navn til gruppen og et slogan for gruppens identitet. I skal beskrive baggrunden for gruppens navn og slogan $i$ et dokument, som I oploader i den elektroniske konference. For naste undervisningsgang, hvor vi arbejder med cafemodellen med tre deltagende grupper, som skiftes til at agere $i$ rollen som henholdsvis fokusgruppe supervisionsgruppe og iagttagergruppe, har I til opgave at satte Jer grundigt ind $i$ hinandens dokumenter. På cafeen skal den enkelte projektgruppe vare forberedt på at prosentere gruppens identitet mundtligt for de to andre grupper $i$ cafeen $i$ ca. 10 minutter, herefter vil den gruppe, der fungerer som supervisionsgruppe, sporge undersegende ind til afklaringsprocessen, betydningen af navn og slogan for gruppeidentiteten mv. denne samtale varer max 25 minutter. Derefter har iagttagergruppen til opgave at samle op på samtalen, beskrive dens dynamik og pege på perspektiver $i$ samtalen, så fokusgruppen fär noget med tilbage at reflektere over. Opsamlingen varer max 10 minutter.

Efter en runde på $i$ alt 45 minutter skifter grupperne roller $i$ cafemodellen og fortsetter runden, indtil alle grupper har provet alle roller.

\section{Hvordan gennemføres cafemodellen i praksis?}

Som nævnt tildeles hver projektgruppe forskellige roller undervejs i forløbet. Nedenfor beskriver jeg de tre forskellige roller, som grupperne varetager på skift.
De tre gruppers roller og samtalens proces

Fokusgruppen præsenterer sit emne i 10 minutter. Herefter besvarer gruppen spørgsmål fra supervisionsgruppen. Fokusgruppen deltager i dialogen med supervisionsgruppen i overensstemmelse med det fælles forarbejde, ligesom fokusgruppens medlemmer undervejs lytter til hinandens svar. Det er ikke tilladt at underkende hinandens idéer eller at fastholde egne kæpheste. Hvis der opstår uenigheder, gøres de til genstand for nye undersøgelser. Supervisionsgruppens rolle er at imødekomme fokusgruppens præsentation og emne med åbne spørgsmål, som kan hjælpe med at belyse og undersøge emnet yderligere. Det er supervisionsgruppens rolle at give fokusgruppen lejlighed til at udtrykke sig nuanceret og formidlende om dens arbejde, om processer heri samt om det aktuelle emne for cafeen.

Det er ikke tilladt at dømme fokusgruppens arbejde, udsagn eller at kritisere ukonstruktivt. Samtalen varer max 25 minutter.

Iagttagergruppens rolle er først og fremmest at lytte aktivt til dynamikken mellem fokusgruppen og supervisionsgruppen og tage notater til samtalens forløb, emner og spring. Hvilke spørgsmål virker øjenåbnende for fokusgruppen? Er der emner/områder, supervisionsgruppen overser? Hvilke ideer bliver forladt af fokusgruppen, og hvordan sker dette? Hvilke dilemmaer eller problemstillinger ser ud til at stå anderledes for fokusgruppen efter denne samtale? Iagttagergruppen samler op ved at beskrive og perspektivere samtalen i max 10 minutter.

\section{Timeout}

I gennemførelsen af samtalen kan man vælge at anvende en strategi, der hedder timeout. Strategien går ud på, at man aftaler et stop i samtalen, som kan bruges til at skabe klarhed over samtalens proces eller emne. Fokusgruppen kan eksempelvis anvende timeout til at bringe samtalen tilbage på sporet, hvis gruppen oplever, at samtalens fokus flytter sig for hurtigt. Eller supervisionsgruppen kan anvende timeout, hvis medlemmerne har brug for at meta-samtale om, hvilke emner de $ø$ nsker at undersøge nærmere. Supervisionsgruppen kan lave timeout for på et metaplan at drøfte med fokusgruppen, om samtalens proces eller emne er på et vedkommende spor. Desuden kan iagttagergruppen vælge at anvende timeout, hvis den ønsker at gøre supervisionsgruppen eller fokusgruppen opmærksom på, at den anerkendende tilgang ikke bliver håndhævet. Endelig kan grupperne på forhånd have aftalt at anvende timeout som redskab til metarefleksion i samtalen. Ellers spiller iagttagergruppen generelt rollen som den metareflekterende part i cafemodellen.

\section{Spørgeteknik}

Foruden timeouts er spørgeteknik og spørgsmålskategorier en nyttig hjæalp i forståelsen af rollerne i samtalen og til at understøtte bevægelse og dynamik i samtalen. 


\begin{tabular}{|c|c|}
\hline $\begin{array}{l}\text { Lineære spørgsmål } \\
\text { Anvendes til at afklare } \\
\text { hændelser, årsager, facts. } \\
\text { Spørger er en art detektiv. } \\
\text { Spørgsmålstyper: } \\
\text { Hvad? } \\
\text { Hvor? } \\
\text { - Hvornår? }\end{array}$ & $\begin{array}{l}\text { Cirkulære spørgsmål } \\
\text { Anvendes til at undersøge } \\
\text { adfærd, perspektiver, } \\
\text { kontekster evt. bagud } \\
\text { i tid. Spørger er en art } \\
\text { opdagelsesrejsende eller } \\
\text { antropolog, som undersøger } \\
\text { forskelle, perspektiver og } \\
\text { synsvinkler. } \\
\text { Spørgsmålstyper: } \\
\text { Beskrivende: Karakteriser } \\
\text { forskelle fra for ti år siden } \\
\text { til nu? } \\
\text { - Forklarende ud fra forskel, } \\
\text { perspektiv, synsvinkel: } \\
\text { Hvordan ville X opfatte } \\
\text { handlingen, som Q foretog } \\
\text { sig? }\end{array}$ \\
\hline $\begin{array}{l}\text { Strategiske spørgsmål } \\
\text { Anvendes for at fremkalde } \\
\text { en virkning, handling eller et } \\
\text { indblik Spørger er vidende } \\
\text { og foran i samtalen. } \\
\text { Spørgsmålstyper: } \\
\text { Konfronterende: Hvor } \\
\text { meget må det koste at..? } \\
\text { Opfordrende: Hvem } \\
\text { skal kontaktes for at få } \\
\text { oplysning om..? } \\
\text { Ledende: Overvej, hvad du } \\
\text { vil prioritere, hvis..? }\end{array}$ & $\begin{array}{l}\text { Refleksive spørgsmål } \\
\text { Anvendes med henblik } \\
\text { på at skabe ny indsigt og } \\
\text { nye handlemuligheder, } \\
\text { fremadrettet og stimulerer } \\
\text { til refleksion } \\
\text { Spørger: undrer sig, } \\
\text { anerkender, coacher } \\
\text { Spørgsmålstyper: } \\
\text { Tidsmarkerende: Hvordan } \\
\text { ser dette ud, om et år - } \\
\text { og hvad er der sket i } \\
\text { mellemtiden? } \\
\text { Hypotetiske spørgsmål: } \\
\text { Hvis X siger ja, betyder } \\
\text { det så noget for P? }\end{array}$ \\
\hline
\end{tabular}

Figur I: Karl Tomms spørgsmålskategorier kan anvendes som inspiration eller som et redskab i cafemodellen.

Figur 1 illustrerer nogle spørgsmålskategorier, der kan anvendes som redskab til at styrke deltagernes opmærksomhed på at arbejde anerkendende og undersøgende i samtalen. Spørgsmålstyperne er udviklet af Karl Tomm og hviler på en systemisk tankegang i overensstemmelse med cafemodellens principielle grundlag.

\section{Erfaringer med at anvende cafemodellen}

Den konkrete ramme om mine erfaringer med cafemodellen er det første hold studerende optaget på kandidatuddannelsen i Oplevelsesøkonomi ved Nordisk Institut, Aarhus Universitet i 2007. Holdet på 49 studerende har bachelorgrader fra humaniora, samfundsvidenskab, naturvidenskab, ASB, AAA, Designskolen samt udenlandske universiteter. Uddannelsen har til formål at give de studerende kompetencer til at kunne analysere, innovere og udvikle projekter inden for Oplevelsesøkonomien, som i denne sammenhæng forstås som en dynamisk kulturel samfundsmæssig ramme. Forløbet, som blev understøttet af cafemodellen, hedder Entrepreneurship - koncept og forretningsudvikling (10 ECTS) og ligger på uddannelsens første semester. Dette forløb i entrepreneurship er undervisning, som tager udgangspunkt i den studerendes faglige og personlige kompetencer og har som mål at transformere kompetencerne til objektive færdigheder, som skal gøre den studerende $\mathrm{i}$ stand til at handle mulighedsorienteret $\mathrm{i}$ en kontekstuel sammenhæng. Der er tale om undervisning, der har som læringsmål, at den studerende med en øget bevidsthed om sine faglige metoder og praksisformer kan koble sig på og samarbejde i flerfaglige projekter. Forløbet er skemalagt med en fast ugentlig undervisningsdag med tre timer, og undervisningen er tilrettelagt med henblik på høj grad af involvering af de studerende i selve undervisningstimerne såvel som mellem undervisningsgangene: Efter hver forelæsning ligger en øvelse, som de studerende besvarer i deres projektgruppe. Besvarelsen (8-10 sider) skal være oploadet $\mathrm{i}$ en elektronisk konference tre dage senere og være forberedt af cafemodellens deltagende grupper før den følgende undervisningsgang, hvor projektgrupperne modtager og giver hinanden anerkendende feedback. Besvarelsen af rækken af øvelser danner en portfolio, som er grundarbejdet i eksamensopgaven, der indleveres i projektgrupper og forsvares mundtligt.

\section{Instruktion og avelse er vigtige elementer}

Fra første undervisningsforløb erfarede jeg, at cafemodellen kræver grundig instruktion. Det gælder beskrivelsen af rollernes funktion i samtalen og processen i samtalen, og det gælder den anerkendende tilgang og de spørgeteknikker, der understøtter denne tilgang til forskel fra den traditionelt kritiske akademiske tilgang. Grundig instruktion er nødvendig dels for de deltagende projektgrupper, dels for det deltagende lærerteam. Instruktionen kan med fordel både udleveres som et handout med beskrivelse af samtalens tre funktioner og med spørgsmålstypologier, men hverken rolle eller spørgsmålstype kan læres som tekst eller teori; det er nødvendigt at praktisere og gøre sig erfaringer med rollerne for at forstå den enkelte gruppes funktion $\mathrm{i}$ samtalen. I det aktuelle forløb var det især iagttagerrollen, der gav både studerende og undervisere stof til eftertanke. Vi oplevede, hvor stærk trangen til at ytre sig er, og hvor meget den skal tøjles, hvis dialogen med fokusgruppen ikke skal blive præget af tilfældige kommentarer. Det var utroligt lærerigt for både undervisere og cafedeltagere at opleve, hvor aktiv lyttepositionen er $i$ en samtale. I starten af det første forløb deltog lærerne $i$ en art refleksiv position i den enkelte cafe. Men det viste sig ikke at være hensigtsmæssigt, dels fordi lærerteamet selv var for uøvede i cafemodellens roller og samtaleteknik, og dels fordi opgaven jo allerede blev varetaget af iagttagergruppen. I stedet vil jeg anbefale, at cafemodellen instrueres grundigt gennem små øvelser med samtalemodellen, hvor der i plenum er lejlighed til at stille spørgsmål på baggrund af opstået tvivl og erfaringer. Efter bare få erfaringer med cafemodellen viste motiveringen af arbejdsformen sig ikke at være 
nogen stor opgave. Grunden var, at den enkelte gruppe oplevede at fă feedback, der var meningsfuld og som gav konkrete anvisninger til en videre arbejdsproces.

\section{Cafegrupperne bor etableres fra start}

Det er en anden væsentlig erfaring, at cafegrupperne bør etableres fra starten, så de samme grupper mødes i cafeerne hen over semestret. Det giver mulighed for at se projekterne $\mathrm{i}$ en proces og for at give grundig feedback på såvel projektemne som proces og samarbejde. De studerende får oplevelsen af og erfaring med at være hinandens kompetente fagfæller.

\section{De studerendes evaluering af cafemodellen: Lærerigt men krævende!}

Brugen af cafemodellen skal naturligvis ses $i$ lyset af de læringsmål og arbejds- og prøveformer, det enkelte undervisningsforløb er beskrevet gennem. I forbindelse med undervisningen i entrepreneurship udviklede vi cafemodellen for at understøtte de studerendes samarbejde på tværs af fag med processer som skal bevidstgøre dem om hver deres faglige og personlige styrker, om fagligt begrundede metoder og antagelser, og som skal styrke dem i deres handlekraft. Det var en vigtig udfordring at etablere en nysgerrig og tillidsfuld synsvinkel på de faglige forskelle mellem bachelorer fra vidt forskellige fakulteter og læringsmiljøer. Den anerkendende tilgang giver mulighed for at se forskelle som ressourcer og imødekomme fagligt forskellige antagelser med en undersøgende tilgang. Det er hensigten, at cafemodellens samtalepositioner fungerer som et redskab og en ramme, der gør de studerende i stand til at give hinanden feedback ud fra et anerkendende grundlag, der kan stimulere gruppernes dialog. Erfaringen fra anvendelsen af cafemodellen hen over semestret er, at den stort set fungerede efter hensigten. Og i forbindelse med den mundtlige eksamen blev det for alvor tydeligt for både studerende og undervisere, hvor meget den anerkendende tilgang og træningen i samtalens tale- og lyttepositioner havde styrket den enkelte studerende $i$ forhold til at sprogliggøre processer, tage åbent imod spørgsmål og i sin dialog være sikker på at tage udgangspunkt i egne faglige og personlige forudsætninger. Af den elektroniske evaluering af forløbet fremhæves cafemodellen også som et centralt element $i$ den enkeltes udbytte af forløbet. På det åbne spørgsmål Hvad larte du mest af? Lyder nogle af svarene:

- Cafe-møderne. Det er i udvekslingen mellem de studerende, at der sker noget spandende og brugbart. Her kommer man til at reflektere over, hvordan andre uden for gruppen opfatter projekt og proces. Det er også her, man deler erfaringer osv.

- At vare del af en gruppe, som arbejder og forhandler sig igennem en proces og frem mod et koncept, hvor alle har kunnet bidrage. Cafemøderne har også varet gavnlige til at få nye perspektiver på ens projekt, dog har der måske varet lidt for mange af dem..

- Ved ikke, måske café-model - når de fungerede efter hensigten.

Som de sidste citater antyder, har i hvert fald er par studerende oplevet, at udbyttet af cafemodellen var svingende, og de studerende beskriver også ret grundigt i evalueringen, at de har oplevet forløbet som en overordentlig stor arbejdsbyrde. I arbejdsbyrden og det store arbejdspres ligger der imidlertid også et fagligt begrundet pres fra undervisernes side på de studerende for, at de skal forstå og erfare i en vedvarende interaktion, som involverer og påvirker den enkelte personligt og fagligt, samtidigt med at de driver et projekt frem. Det vil sige, at mens de studerende arbejder på højtryk i deres projektgrupper, oplever de at yde med nogle kompetencer og sider af sig selv, som de ikke har prøvet før. Og de oplever at dette bidrager til at skabe en anden type undervisningsmiljø, end de med meget stor sandsynlighed har mødt før. ${ }^{2}$

\section{Perspektivering - læring i et fagligt praksisfællesskab}

Det er en erfaring fra anvendelse af systemiske og anerkendende samtaler i forbindelse med kollegial supervision blandt undervisere ved Humaniora på AU, at underviserne oplever at få redskaber, som de kan anvende i undervisning og vejledning. ${ }^{3}$ Derfor har det været en enkel manøvre at fortsætte tanken: Hvis samtale er et vigtigt redskab for underviserne i undervisningen og det kollegiale samarbejde, kan samtale så ikke også blive det for de studerende i deres faglige samarbejde? Det, der har interesseret mig i eksperimentet med cafemodellen som feedbackform, er spørgsmålet om, hvordan vi gør de studerende $i$ stand til at spille en tydeligere rolle for hinanden som kompetente deltagere $i$ et fagligt fællesskab? Grunden til spørgsmålet er, at jeg dels som underviser selv oplever, at underviseren tillægges meget stor betydning af de studerende, og at jeg dels hører andre undervisere fortælle om den samme erfaring. Nogle studerende udtrykker direkte, at de foretrækker at høre underviseren frem for deres medstuderende, at de er usikre på hinandens kunnen og dermed bliver det vanskeligt for de studerende at håndtere arbejde på egen hånd og samarbejde i grupper. Der kan være flere grunde til, at underviseren står så centralt for de studerende. En af forklaringerne på de studerendes ønske om mere tid med underviseren kan være deres behov for at lære igennem iagttagelse af faget i praksis, dvs. at få lov til at se underviseren agere i faget. Så hvis vi ønsker at styrke de studerendes mulighed for at lære mere bredspektret og styrke deres kompetence til at agere kompetent over for hinanden, så skal vi styrke de studerendes mulighed for at praktisere fagligheden og gøre dem i stand til at forholde sig til hinanden som 
dele af et lærende fællesskab. Cafemodellen beskriver en aftalt form på samtalen, som rammesætter tale og lytte-positioner og giver redskaber i form af spørgsmålskategorier. De studerende øver sig $\mathrm{i}$ at forpligte sig $i$ et lærende fællesskab, hvor det ikke er underviseren, men de studerende selv, der har hovedrollen. De lærer at agere $i$ faget ved selv at agere.

\section{Noter}

1 Cafemodellen kan minde om cafemetoden, som er en udbredt metode til at understøtte videndeling i grupper og et anerkendt værktøj til at facilitere gruppeprocesser. Cafeen indrettes ved borde, der har 3-6 "gæster« og en "vært«, som drøfter et fastlagt tema.Værten kan invitere nye gæster til at deltage i diskussion fra tilstødende cafeborde.

2 I kombinationen af foretagsomhed som et specifikt entrepreneurielt læringsmål og cafemodellens systemiske og anerkendende samtale, ligger der stof til en dybere diskussion af læringsteoretiske tilgange til udvikling af undervisningsformer på universiteterne. Det er en omfattende og spændende diskussion, som har jeg bl.a. har taget hul på med Per Blenker i artiklen "Bevidsthed om læring - en kompetence med udgangspunkt i entrepreneuriel undervisning", i Arbejdspapir nr. 1, 2008, Center for Undervisningsudvikling, AU. Artiklen ligger i elektronisk version på www.cfu.dk

3 Leth Andersen og Søndergaard, 2007: Kollegial supervision på universitetet, Aarhus Universitetsforlag. 


